\title{
Ozone production and trace gas correlations during the June 2000 MINATROC intensive measurement campaign at Mt. Cimone
}

\author{
H. Fischer ${ }^{1}$, R. Kormann ${ }^{1}$, T. Klüpfel ${ }^{1}$, Ch. Gurk ${ }^{1}$, R. Königstedt ${ }^{1}$, U. Parchatka ${ }^{1}$, J. Mühle ${ }^{1}$, T. S. Rhee ${ }^{1}$, C. A. M. \\ Brenninkmeijer $^{1}$, P. Bonasoni ${ }^{2}$, and A. Stohl ${ }^{3}$ \\ ${ }^{1}$ Max Planck Institute for Chemistry, POB 3060, 55020 Mainz, Germany \\ ${ }^{2}$ National Research Council, Institue of Atmospheric Sciences and Climate, via Gobetti 101, 40129 Bologna, Italy \\ ${ }^{3}$ Technical University of Munich, Chair of Bioclimatology and Air Pollution Research, Am Hochanger 13, 85354 \\ Freising-Weihenstephan, Germany
}

Received: 1 July 2002 - Published in Atmos. Chem. Phys. Discuss.: 7 October 2002

Revised: 6 June 2003 - Accepted: 6 June 2003 - Published: 16 June 2003

\begin{abstract}
An intensive measurement campaign was performed in June 2000 at the Mt. Cimone station $\left(44^{\circ} 11^{\prime}\right.$ $\mathrm{N}-10^{\circ} 42^{\prime} \mathrm{E}, 2165 \mathrm{~m}$ asl, the highest mountain in the northern Italian Apennines) to study photochemical ozone production in the lower free troposphere. In general, average mixing ratios of important trace gases were not very high (121 \pm 20 ppbv CO, $0.284 \pm 0.220$ ppbv NOx, $1.15 \pm 0.8 \mathrm{ppbv}$ $\mathrm{NOy}, 58 \pm 9$ ppbv $\mathrm{O}_{3}$ ), which indicates a small contribution by local pollution. Those trace gas levels are representative of continental background air, which is further supported by the analysis of VOCs (e.g.: $\mathrm{C}_{2} \mathrm{H}_{6}=(905 \pm 200)$ pptv, $\mathrm{C}_{3} \mathrm{H}_{8}$ $=(268 \pm 110)$ pptv, $\mathrm{C}_{2} \mathrm{H}_{2}=(201 \pm 102)$ pptv, $\mathrm{C}_{5} \mathrm{H}_{8}=(111$ $\pm 124)$ pptv, benzene $=(65 \pm 33)$ pptv $)$. Furthermore, significant diurnal variations for a number of trace gases $\left(\mathrm{O}_{3}\right.$, $\mathrm{CO}, \mathrm{NOx}, \mathrm{NOy}, \mathrm{HCHO}$ ) indicate the presence of free tropospheric airmasses at nighttime as a consequence of local catabatic winds. Average mid-day peroxy radical concentrations at Mt. Cimone are of the order of 30 pptv. At mean NO concentrations of the order of $40 \mathrm{pptv}$ this gives rise to significant in situ net $\mathrm{O}_{3}$ production of $0.1-0.3 \mathrm{ppbv} / \mathrm{hr}$. The importance of $\mathrm{O}_{3}$ production is supported by correlations between $\mathrm{O}_{3}, \mathrm{CO}, \mathrm{NOz}$, and $\mathrm{HCHO}$, and between $\mathrm{HCHO}, \mathrm{CO}$ and NOy.
\end{abstract}

\section{Introduction}

Ozone in the troposphere originates either from the stratosphere by downward transport to the troposphere at extratropical latitudes, often in connection with tropopause folding events (e.g. Holton et al., 1995 and references therein), or from in-situ photochemical production involving $\mathrm{NOx}, \mathrm{CO}$,

Correspondence to: H. Fischer

(hofi@mpch-mainz.mpg.de) and hydrocarbons (e.g. Crutzen, 1995). In rural and remote environments an important fraction of the tropospheric ozone is due to in-situ photochemical production. It is well established by model studies and observations that ozone production in remote areas is usually limited by the availability of NOx. Photochemical ozone production has been studied extensively in rural environments (see Kleinman, 2000 and Trainer et al., 2000) for recent reviews of observationbased analysis of ozone production in rural environments), while studies in the remote troposphere are less common ( $\mathrm{Ri}$ dley and Robinson, 1992; Atlas and Ridley, 1996; Fischer et al., 1998; Zanis et al., 2000a; Zanis et al., 2000b). Often, free tropospheric measurements are obtained from airborne investigations, which place limitations on the number of species that can be measured and on their temporal coverage. As an alternative, high-altitude measurements at mountainous sites can be used to yield information on the free troposphere, provided that local orographic influences can be quantified. To determine the net ozone production and the oxidizing power of the free troposphere, accurate measurements of the photolysis frequencies of $\mathrm{O}_{3}$ and $\mathrm{NO}_{2}$, as well as sensitive measurements of the concentrations of $\mathrm{NO}, \mathrm{NO}_{2}$, $\mathrm{O}_{3}$, ROx, CO, and VOCs have to be made. In addition, measurements of formaldehyde ( $\mathrm{HCHO}$ ), an intermediate species originating from the photochemical degradation of $\mathrm{CH}_{4}$ and NMVOCs (non-methane volatile organic compounds), can be used to gain information about the level of chemical activity (Wagner et al., 2002). In June 2000 an intensive measurement campaign was performed at Mt. Cimone $\left(44^{\circ} 11^{\prime} \mathrm{N}\right.$, $10^{\circ} 42^{\prime} \mathrm{E}, 2165 \mathrm{~m}$ asl) (Bonasoni et al., 2000) to study ozone formation in the free troposphere over this part of continental Europe. Accurate measurements of $\mathrm{NO}, \mathrm{NO}_{2}, \mathrm{HNO}_{3}, \mathrm{NOy}$ (sum of reactive nitrogen species), $\mathrm{O}_{3}, \mathrm{HCHO}, \mathrm{CO}, \mathrm{CH}_{4}$, NMVOCs, $\mathrm{HO}_{2}, \mathrm{RO}_{2}, \mathrm{O}_{3}$ photolysis frequency, aerosol and 
meteorological parameters were performed by a consortium of European institutes in the framework of MINATROC (MINeral dust And TROpospheric Chemistry). An overview of the goals of MINATROC in general and the Mt. Cimone experiment in particular can be found in Balkanski et al. (this issue).

\section{Trace gas measurements at Mt. Cimone}

The instrumentation operated by the Max Planck Institute for Chemistry was housed in a laboratory building while air sampling was accomplished at a height of $8 \mathrm{~m}$ above the roof of the building using a telescopic mast. The air was transferred to the instruments using 1/4" OD PFA tubing wrapped in black sealing to avoid photochemical decomposition of photolabile species inside the sampling lines.

A Tunable Diode Laser Absorption Spectroscopy (TDLAS) instrument was used for the measurement of $\mathrm{NO}_{2}$, $\mathrm{HCHO}$, and $\mathrm{H}_{2} \mathrm{O}_{2}$. The TDLAS is described in detail in (Wienhold et al., 1998; Kormann et al., 2002). Absorption lines at $1608.1 \mathrm{~cm}^{-1}$ (antisymmetric streching vibration), $1760.9 \mathrm{~cm}^{-1}$ (C-O stretching vibration) and $1248.0 \mathrm{~cm}^{-1}$ (O-H bending vibration) were used for $\mathrm{NO}_{2}, \mathrm{HCHO}$ and $\mathrm{H}_{2} \mathrm{O}_{2}$, respectively. The time resolution of the original data is $90 \mathrm{sec}$. In-situ calibrations were performed every $15 \mathrm{~min}$ by replacing ambient air with known amounts of calibration gas standards (permeation devices) while zero gas measurements were made every $90 \mathrm{sec}$, applying scrubbed ambient air to the inlet (Kormann et al., 2002). The uncertainty of the calibration gas standards was estimated to be of the order of $10 \%$. The precision, deduced from the reproduceability of the infield calibrations was $1.9 \%\left(\mathrm{NO}_{2}\right)$ and $2.6 \%(\mathrm{HCHO})$, while the detection limit was $46 \mathrm{pptv}\left(\mathrm{NO}_{2}\right)$ and $102 \mathrm{pptv}(\mathrm{HCHO})$ for the $90 \mathrm{sec}$ time resolution. Post campaign averaging of the data over $30 \mathrm{~min}$ further improved the precision and detection limit of those measurements. Reliable data for $\mathrm{H}_{2} \mathrm{O}_{2}$ could not be gained due to a technical problem with the laser diode used for this species.

Total reactive nitrogen (NOy) was measured after conversion to $\mathrm{NO}$ in a heated $\mathrm{Au}$-converter in the presence of $\mathrm{CO}$ using a chemiluminescence detector (Tecan CLD $770 \mathrm{ppt}$ ). The Au- converter was mounted on top of the sample mast thus avoiding the need for an additional inlet line (Lange et al., 2002). Zero and calibration gas $\left(\mathrm{NO}, \mathrm{NO}_{2}\right)$ were added to the converter every $15 \mathrm{~min}$. The time resolution was $10 \mathrm{sec}$, the accuracy was about $22 \%$, the precision was $14 \%$ and the noise level was 90 pptv. A second CLD was used for NO measurements (time resolution $10 \mathrm{~s}$, accuracy $5 \%$, precision $2.2 \%$, detection limit $3.5 \mathrm{pptv}$ ).

$\mathrm{CO}$ was measured every 4 min using an in-situ gas chromatograph with a gas reduction $(\mathrm{HgO})$ detector $(\mathrm{GC} / \mathrm{HgO})$. The instrument was calibrated every $6 \mathrm{hr}$ using two NOAA traceable secondary standards (accuracy $4.2 \%$ ) with a reproduceability of $1.5 \%$.
A peroxy radical chemical amplifier (PERCA), based on the design of Hastie et al. (1991), was used for the measurement of peroxy radicals (ROx). The instrument is placed in a small refrigerator regulated to $280 \mathrm{~K}$ (Perner et al., 1999) mounted on top of the laboratory building $(1.5 \mathrm{~m}$ above the roof). The chain length of the radical amplifier was determined three times during the campaign using the photolysis of $\mathrm{H}_{2} \mathrm{O}$ as a source of $\mathrm{HO}_{2}$ radicals (Schultz et al., 1995). As shown by Mihele and Hastie (1998), the chain length of a PERCA is sensitive to the concentration of ambient water. Therefore, the chain length was determined in the laboratory as a function of the water vapor concentration, and the field data were corrected after the campaign based on measurements of the relative humidity. The detection limit of the PERCA used is better than 7 pptv (typically 2 pptv @ $1 \mathrm{~min}$ time resolution), the noise level (1 min time resolution) is $8-10 \mathrm{pptv}$, and the accuracy is $40-60 \%$. Note that additional measurements of $\mathrm{HO}_{2}$ and $\mathrm{RO}_{2}$ were made by the Max Planck Institute for Nuclear Research in Heidelberg using the ROXMAS technique. Details of these measurements and a comparison of the total ROx levels measured by the two instruments can be found in (Uecker et al., 2001; Hanke et al., 2002).

Ozone mixing ratios were determined every $60 \mathrm{sec}$ from UV absorption measurements (Ansyco $41 \mathrm{M}$ ) with an accuracy better than $5 \%$, while the ozone photolysis rate $\left(\mathrm{J}\left(\mathrm{O}^{1} \mathrm{D}\right)\right)$ was measured using two filter radiometers (Meteorology Consult), measuring the up- and downward flux of radiation in the UV-B range with a total uncertainty of 20$50 \%$ depending on solar zenith angle. An additional ozone measurement was performed at the station by CNR-ISAO (UV-Absorption Dasibi, inlet $\sim 8 \mathrm{~m}$ above the ground). A linear regression analysis yielded $\mathrm{O}_{3}(\mathrm{CNR}-\mathrm{ISAO})=0.89 \mathrm{O}_{3}$ $(\mathrm{MPI}-\mathrm{C})+8, \mathrm{R}^{2}=0.82$, indicating a tendency for higher $\mathrm{O}_{3}$ concentrations obtained by the MPI-C instrument. Since an in-field comparison of the calibration standards was not performed, this discrepancy remains unresolved.

In addition to these in-situ measurements, 26 stainless steel electropolished canisters were filled for postcampaign analysis of volatile organic compound (VOC) (ethane, ethene, propane, propene, isobutane, butane, acetylene, trans-2-butene, 1-butene, cis-2-butene, 2-methylbutane, pentane, cyclohexane, 2-methylpentane, 3-methylpentane, hexane, isoprene, benzene) and for greenhouse gases (sulfur hexafluoride, carbon dioxide, methane, nitrous oxide). The VOC analysis was made in the home laboratory using gas chromatography with mass spectrometric detection (GC/MS) (Mühle et al., 2002). The 26 samples were separated on a $50 \mathrm{~m}, 0.32 \mathrm{~mm} \mathrm{ID,} 5 \mu \mathrm{m} \mathrm{Al}_{2} \mathrm{O}_{3} / \mathrm{KCl}$ porous layer open tubular (PLOT) column (Chrompack) by using a gas chromatograph (Hewlett-Packard, HP 6890) connected to a quadrupole mass spectrometer (HP 5973). A 30 compound reference standard from the National Physical Laboratory (Teddington, UK) with a certified uncertainty range of 1.2 to $2.2 \%$ (95\% confidence limit) for each compound was used 


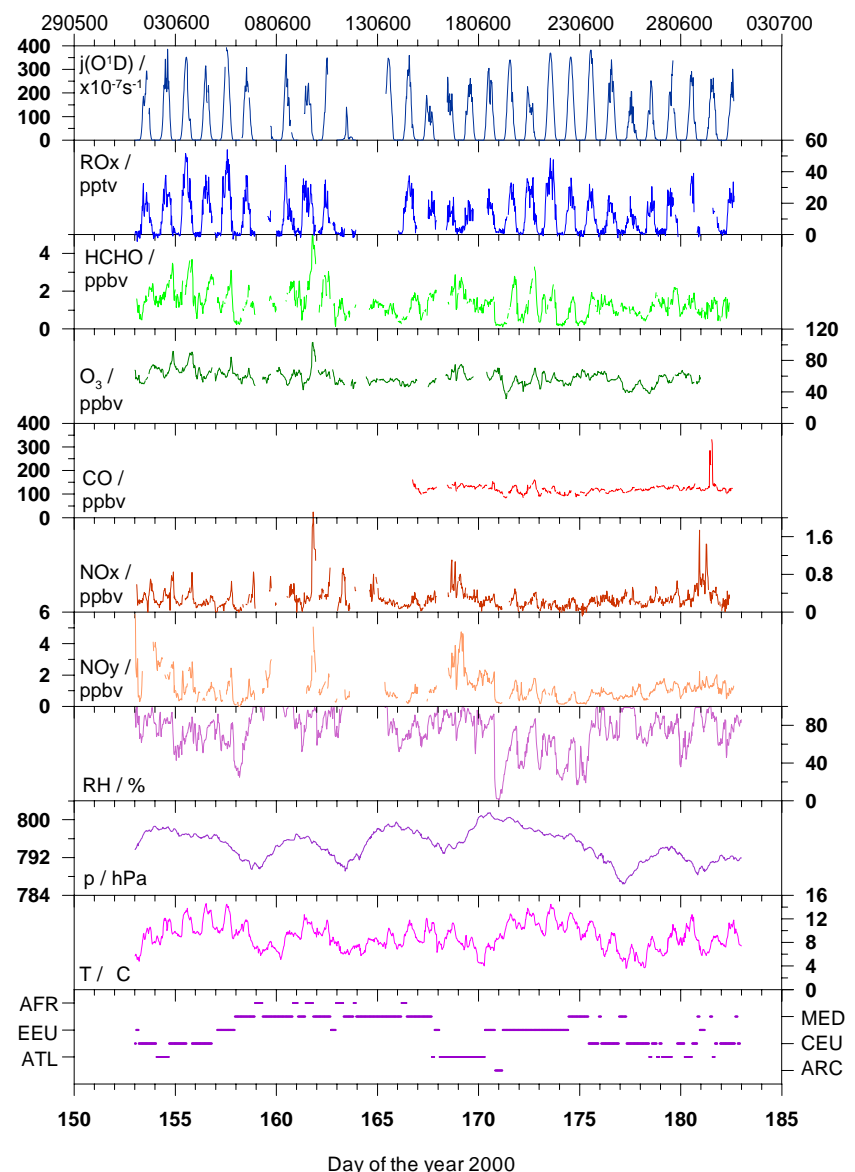

Fig. 1. Time series ( $30 \mathrm{~min}$ resolution) of trace gas mixing ratios, ozone photolysis rate, and meteorological parameters obtained during the MINATROC intensive campaign at Mt. Cimone, Italy. The lower panel indicates the airmass origin (Arctic (ARC), NorthWestern Europe (NWEU), Western Europe (WEU), Eastern Europe (EEU), Mediterranean Basin (MED), Saharan-African (AFR)) deduced from 144-hour backward-trajectories.

for absolute calibration. The detection limits ( $3 \sigma$ variation of a blank sample) were 1 to $7.4 \mathrm{pptv}$ (alkanes), 0.3 to $2.7 \mathrm{pptv}$ (alkenes) and 8 pptv (acetylene, benzene) and the precision is 1 to $15 \%$.

Additional measurements of meteorological parameters ( $\mathrm{T}, \mathrm{p}, \mathrm{RH}$, wind speed and direction) were made by CNRISAO. For the following data analysis, a merged data set based on 30 min averages of the in-situ data has been used.

\section{Results and Discussion}

\subsection{Data overview}

Near-continuous, 24-hour measurements were made during the intensive measurement period between 1-30 June, with the exception of $\mathrm{CO}$, which was measured only after 14 June.
Canister samples were taken on 6 June ( 2 samples), 7 June (2 samples), 9 June (3 samples), 10 June (1 sample), 14 June (3 samples), 15 June (1 sample), 19 June (2 samples), 27 June (1 sample), 28 June (1 sample), 29 June (1 sample), 2 July (1 sample), 3 July (3 samples), 4 and July (4 samples). Figure 1 shows the time series for $\mathrm{J}\left(\mathrm{O}^{1} \mathrm{D}\right)$, ROx $, \mathrm{HCHO}, \mathrm{O}_{3}$, $\mathrm{CO}, \mathrm{NOx}\left(\mathrm{NO}+\mathrm{NO}_{2}\right), \mathrm{NOy}, \mathrm{RH}, \mathrm{p}, \mathrm{T}$, and the airmass origin deduced from back-trajectories. A statistical analysis of the trace gas measurements for the complete data set, and subdivisions into daytime (6-20 GMT) and nighttime (20-6 GMT) observations is given in Table 1 . In general, the trace gas levels are relatively low, indicating that the site is not significantly affected by local pollution. Daytime median levels of $\mathrm{O}_{3}, \mathrm{CO}$, NOx, NOy and $\mathrm{HCHO}$ are $56 \mathrm{ppbv}, 119 \mathrm{ppbv}$, $0.267 \mathrm{ppbv}, 0.897 \mathrm{ppbv}$ and $1.4 \mathrm{ppbv}$, respectively. Median concentrations of ROx are of the order of $17 \mathrm{pptv}$. In particular, the low levels of NOx, NOy and the ratio NOx/NOy $\sim 0.3$ confirm that photochemically aged airmasses are probed at the site. This is further supported by the relatively low levels of NMHC (Table 2). During the night, slightly higher median levels are observed for $\mathrm{O}_{3}(60 \mathrm{ppbv})$ and $\mathrm{NOy}(1.027 \mathrm{ppbv})$, while lower levels are found for NOx (0.197) and HCHO (1.107 ppbv), as compared to daytime conditions. Peroxy radical levels are generally below the detection limit during the night.

Lowest levels for NOx, NOy, $\mathrm{CO}$ and $\mathrm{HCHO}$ were observed during the nights of 5/6,19/20,20/21, 21/22, and $22 / 23$ June. During these nights the relative humidity dropped to values below $40 \%$, while the wind speed generally exceeded $5 \mathrm{~m} / \mathrm{s}$, thus indicating downward transport of air from the free troposphere. This is reflected in the average trace gas levels, which are $78 \pm 53$ pptv for NOx, $254 \pm$ $180 \mathrm{pptv}$ for $\mathrm{NOy}, 56 \pm 8 \mathrm{ppbv}$ for $\mathrm{O}_{3}, 100 \pm 8 \mathrm{ppbv}$ for $\mathrm{CO}$ and $334 \pm 128$ pptv for HCHO. Additional measurements of low concentrations of cloud condensation nuclei (CCN) (van Dingenen et al., this issue), as well as enhanced CO2 concentrations (Bonasoni et al., this issue) further support the interpretation that the airmasses originated from the free troposphere (note that in summer $\mathrm{CO}_{2}$ concentrations in the continental boundary layer are generally lower than free tropospheric concentrations due to uptake by vegetation, Fischer et al., 2002).

The highest trace gas levels were observed in the late afternoon of 9 June between 18:00 and 23:00 GMT during easterly to south-easterly flow. During this period NOx and NOy increased to 2.2 and $5 \mathrm{ppbv}$, respectively, while maximum $\mathrm{HCHO}$ values of nearly $5 \mathrm{ppbv}$ were measured. Unfortunately $\mathrm{CO}$ was not measured during this first phase of the campaign, but very high concentrations of $\mathrm{CCN}$ of the order of 1.3-1.4 × $10^{5}$ (van Dingenen et al., this issue) and highly elevated $\mathrm{O}_{3}$ concentrations of more than $100 \mathrm{ppbv}$ indicate that most probably photochemically processed polluted boundary layer air masses reached the site.

The lower panel of Fig. 1 documents an airmass classification deduced from 144 hours (6 days) three- 
Table 1. Statistics of trace gas measurements (30 min resolution) during upslope (6-20 GMT) and downslope (20-6 GMT) conditions

\begin{tabular}{lcccccc}
\hline & $\mathrm{O}_{3} / \mathrm{ppbv}$ & $\mathrm{CO} / \mathrm{ppbv}$ & $\mathrm{NOx} / \mathrm{ppbv}$ & $\mathrm{NOy} / \mathrm{ppbv}$ & $\mathrm{CH}_{2} \mathrm{O} / \mathrm{ppbv}$ & $\mathrm{ROx} / \mathrm{pptv}$ \\
All data: & & & & & & \\
Mean & 58 & 121 & 0.284 & 1.151 & 1.356 & 11 \\
Median & 57 & 121 & 0.241 & 0.983 & 1.296 & 7 \\
$1 \sigma-\mathrm{STD}$ & 9 & 20 & 0.220 & 0.807 & 0.721 & 11 \\
Central 50\% & $52-63$ & $120-129$ & $0.155-0.341$ & $0.623-1.442$ & $0.869-1.682$ & $1-20$ \\
Range & $31-103$ & $84-330$ & $0-2.119$ & $0.019-5.885$ & $0.106-4.992$ & $-4-54$ \\
Number & 1163 & 644 & 1143 & 1004 & 1134 & 1088 \\
\hline 6-20 GMT: & & & & & & \\
Mean & 57 & 124 & 0.306 & 1.138 & 1.512 & 18 \\
Median & 56 & 119 & 0.267 & 0.897 & 1.418 & 17 \\
1 $\sigma$-STD & 9 & 24 & 0.204 & 0.999 & 0.692 & 11 \\
Central 50\% & $51-61$ & $108-124$ & $0.193-0.365$ & $0.447-1.400$ & $1.039-1.840$ & $9-25$ \\
Range & $31-103$ & $84-330$ & $0-2.119$ & $0.019-5.855$ & $0.262-4.992$ & $-2-54$ \\
Number & 705 & 370 & 664 & 415 & 650 & 654 \\
\hline 20-6 GMT: & & & & & & \\
Mean & 60 & 117 & 0.253 & 1.159 & 1.145 & 1 \\
Median & 60 & 118 & 0.197 & 1.027 & 1.107 & 1 \\
1 $\sigma$-STD & 9 & 13 & 0.237 & 0.639 & 0.707 & 2 \\
Central 50\% & $54-65$ & $108-125$ & $0.112-0.295$ & $0.713-1.480$ & $0.580-1.482$ & $0-2$ \\
Range & $40-96$ & $85-151$ & $0-1.879$ & $0.113-5.065$ & $0.106-4.442$ & $-4-12$ \\
Number & 458 & 272 & 479 & 589 & 484 & 434 \\
\hline
\end{tabular}

Table 2. Mean trace gas levels and standard deviations in pptv for NMHC measurements based on 26 canister samples collected between 6 June and 4 July 2000

\begin{tabular}{lccc}
\hline NMHCs & Range & Mean & $1 \sigma$-STD \\
\hline Ethane & $575-1446$ & 905 & 200 \\
Ethene & $66-512$ & 261 & 120 \\
Propane & $87-610$ & 268 & 110 \\
Propene & $25-183$ & 75 & 39 \\
Isobutane & $18-255$ & 96 & 50 \\
Butane & $13-387$ & 108 & 68 \\
Acetylene & $67-576$ & 201 & 102 \\
trans-2-Butene & $1-11$ & 5 & 2 \\
1-Butene & $6-37$ & 15 & 8 \\
cis-2-Butene & $1-15$ & 7 & 3 \\
2-Methylbutane & $12-446$ & 110 & 86 \\
Pentane & $4-138$ & 35 & 26 \\
Cyclohexan & $0-29$ & 6 & 7 \\
2-Methylpentane & $2-92$ & 26 & 19 \\
3-Methylpentane & $1-47$ & 14 & 10 \\
Hexane & $3-32$ & 13 & 7 \\
Isoprene & $0-500$ & 111 & 124 \\
Benzene & $22-188$ & 65 & 33 \\
\hline
\end{tabular}

dimensional back-trajectories calculated every 3 hours with the FLEXTRA trajectory model (Stohl et al., 1995). The classification is based on the geographical region over which the airmasses spent most of their time before reaching Mt.
Cimone (Balkansky et al., this issue; van Dingenen et al., this issue), leading to a subdivision into 6 classes: Arctic (ARC), North-Western Europe (NWEU), Western Europe (WEU), Eastern Europe (EEU), the Mediterranean Basin (MED) and the Saharan-African (AFR) area. Table 3 shows trace gas levels (mean $\pm 1 \sigma$-standard deviation calculated for a 3-hour period centered around the time of the back-trajectory calculation) for the different airmass origins. For this evaluation a further subdivision in ascending airmasses from the boundary layer and descending airmasses from the free troposphere has been made, based on the vertical displacement of the back-trajectories. The differences in the trace gas levels for different airmass classes are quite small. In general, lower pollution levels are observed for airmasses descending from the free troposphere, in particular those of Arctic origin. The highest pollution levels are observed for airmasses spending most of their time in the continental boundary layer over north-western Europe.

Beside photochemistry during the day, diurnal variations (Fig. 2) are mainly driven by local meteorology. Diurnal variations of trace gases at high-elevation mountainous sites are generally influenced by local catabatic and anabatic winds (Zaveri et al., 1995). After sunset, radiative cooling of the mountain slopes cools the adjacent air, resulting in downslope flows (catabatic winds). Therefore, high-elevation sites like Mt. Cimone often receive air from the free troposphere during the night. Shortly after sunrise, solar heating warms the air adjacent to the slopes, causing a reversal of the flow, giving rise to upslope (anabatic) winds, that can 
Table 3. Mean trace gas levels for different airmass classifications based on 3D-back trajectories. One-sigma standard deviations are given in parenthesis. For the evaluation descending (FT) and ascending (BL) trajectories have been listed separately

\begin{tabular}{llcccccc}
\hline & Altitude & $\%$ & CO/ppbv & HCHO/ppbv & NOx/ppbv & NOy/ppbv & $\mathrm{O}_{3} /$ ppbv \\
\hline Arctic & BL & NA & NA & NA & NA & NA & NA \\
& FT & 1 & $112(5)$ & $0.230(0.047)$ & $0.111(0.039)$ & $0.250(0.063)$ & $63(5)$ \\
NW-Europe & BL & 9 & $131(8)$ & $1.588(0.492)$ & $0.387(0.205)$ & $2.059(0.997)$ & $60(8)$ \\
& FT & 5 & $129(5)$ & $1.484(0.368)$ & $0.265(0.081)$ & $1.693(0.662)$ & $60(6)$ \\
W-Europe & BL & 15 & $120(8)$ & $1.322(0.533)$ & $0.267(0.117)$ & $1.116(0.766)$ & $56(10)$ \\
& FT & 9 & $118(6)$ & $1.527(0.676)$ & $0.270(0.117)$ & $0.999(0.651)$ & $64(8)$ \\
E-Europe & BL & 11 & $119(15)$ & $1.283(0.580)$ & $0.271(0.184)$ & $1.216(0.633)$ & $60(7)$ \\
& FT & 7 & $113(17)$ & $1.212(0.874)$ & $0.184(0.119)$ & $0.758(0.481)$ & $53(7)$ \\
Mediterranian & BL & 26 & $128(46)$ & $1.314(0.754)$ & $0.321(0.502)$ & $0.945(0.747)$ & $57(8)$ \\
\multirow{2}{*}{ Africa } & FT & 6 & $106(10)$ & $0.956(0.494)$ & $0.337(0.162)$ & $0.531(0.277)$ & $55(6)$ \\
& BL & 6 & NA & $1.639(1.049)$ & $0.351(0.666)$ & $1.158(0.666)$ & $57(10)$ \\
& FT & NA & NA & NA & NA & NA & NA \\
\hline
\end{tabular}

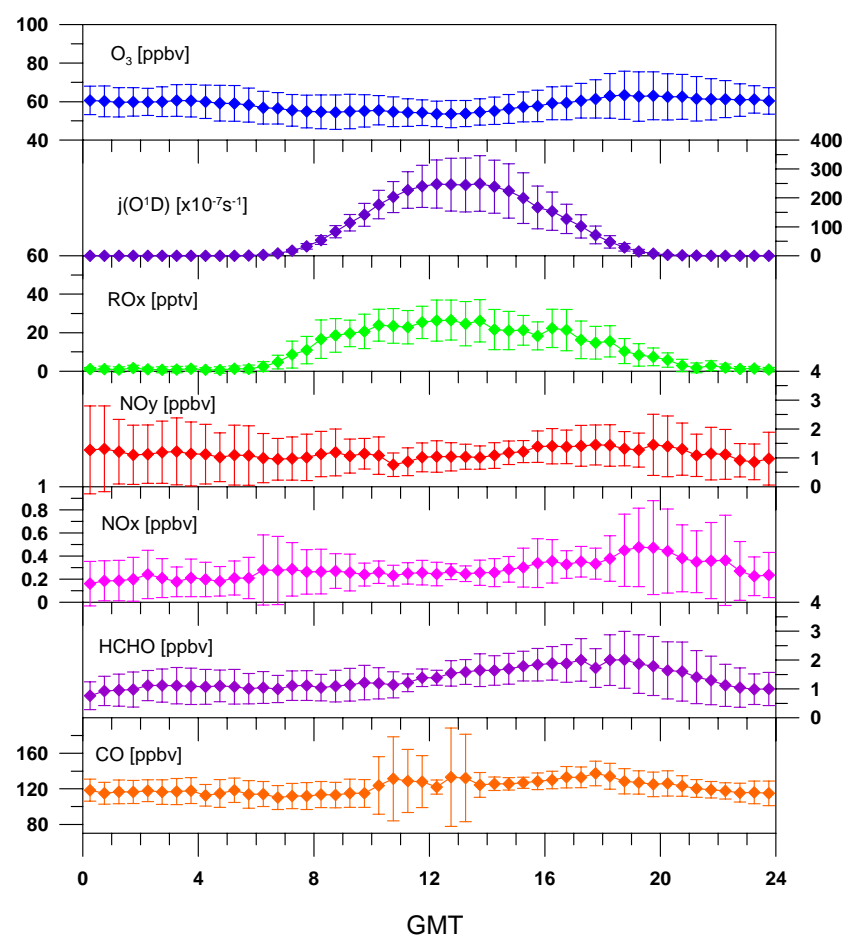

Fig. 2. Diurnal variation (mean $\pm 1 \sigma$-standard deviation) of trace gas measurements at Mt. Cimone.

bring polluted air from the continental boundary layer to the site. At Mt. Cimone weak diurnal variations are observed for $\mathrm{NOx}, \mathrm{NOy}, \mathrm{O}_{3}$ and $\mathrm{CO}$ (Fig. 2). As expected, pollutant levels are higher during the day (see Table 1), due to transport of boundary layer air to the site, but the ratio of $\mathrm{NOx} / \mathrm{NOy}$, which is approximately $0.3(0.29 \pm 0.16)$, indicates transport of photochemically processed airmasses to the site. An exception is the higher concentration of NOy during the night. This is partly due to a bias in the nighttime NOy data due to the strong enhancements observed during the night of $9 / 10$ June (see Fig. 1). Much stronger diurnal variations are observed for ROx and HCHO. For these species the diurnal variation is much more dependent on local photochemistry rather than transport, producing high values during the day (Fig. 2 and Table 1).

Additional measurements of $\mathrm{HNO}_{3}$ were performed by the Max Planck Institute for Nuclear Physics (Hanke et al., this issue). The calculated ratio between $\mathrm{HNO}_{3}$ and $\mathrm{NOy}$ is close to unity (mean $\pm 1 \sigma$-standard deviation: $0.9 \pm 2.8$ ), with $40 \%$ of all ratios larger than one. A linear regression indicates a significant offset of the order of $0.5 \mathrm{ppbv}\left(\mathrm{HNO}_{3}=\right.$ $0.36 \mathrm{NOy}+0.445)$. This offset can be either due to an overestimation of $\mathrm{HNO}_{3}$ or a corresponding underestimation of the measured NOy. If we assume that $\mathrm{HNO}_{3}$ is a rather constant fraction of NOy, an underestimation of NOy by a constant amount could be due to either inlet losses or an underestimation of the $\mathrm{HNO}_{3}$ conversion efficiency of the converter. Since the NOy converter itself acts as an inlet system, losses of $\mathrm{HNO}_{3}$ are very low in our measurement set-up. In-field measurements of the conversion efficiency of the converter for $\mathrm{HNO}_{3}$ were not made, but laboratory tests before and after the campaign demonstrated a good agreement between the $\mathrm{HNO}_{3}$ conversion efficiency and those for $\mathrm{NO}_{2}(97 \%)$ within 5\% (Lange et al., 2002). Although we cannot exclude a systematic underestimation of the NOy measurements by $0.5 \mathrm{ppbv}$, we nevertheless consider this as highly unlikely.

\subsection{Comparison to observations at other remote mountain-} ous sites

It is useful to compare the measurements at Mt. Cimone to spring or summer observations at other high elevation mountainous sites. Table 4 shows a comparison of mean $\mathrm{O}_{3}, \mathrm{CO}$, NOx, NOy, and HCHO trace gas levels, as well as average noontime ROx concentrations observed at Mt. Cimone (Italy, $44.18^{\circ} \mathrm{N}, 10.7^{\circ} \mathrm{E}, 2165 \mathrm{~m}$ asl), Mauna Loa 
Table 4. Comparison of trace levels (upslope/downslope conditions) observed at Mt. Cimone with summer time observations at four other mountainous sites in Europe and the US. The cited ROx levels are average values for noontime

\begin{tabular}{lcccccc}
\hline & Mte. Cimone & Mauna Loa & Izana $^{2}$ & Jungfraujoch $^{3}$ & Jungfraujoch $^{4}$ & Idaho Hill $^{5}$ \\
\hline Lat./Long. & $44.18^{\circ} \mathrm{N} / 10.7^{\circ} \mathrm{E}$ & $19.38^{\circ} \mathrm{N} / 155.36^{\circ} \mathrm{W}$ & $28.18^{\circ} \mathrm{N} / 16.3^{\circ} \mathrm{W}$ & $46.33^{\circ} \mathrm{N} / 7.59^{\circ} \mathrm{W}$ & $46.33^{\circ} \mathrm{N} / 7.59^{\circ} \mathrm{W}$ & $39.5^{\circ} \mathrm{N} / 105.37^{\circ} \mathrm{W}$ \\
Altitude [m] & 2165 & 3400 & 2370 & 3580 & 3580 & 3070 \\
Season & June 2000 & July/August 1992 & July/August 1994 & Summer 1997 & March/April 1998 & August/September 1993 \\
O $_{3}$ [ppbv] & $56 / 60$ & $33.8^{*} / 35.6$ & $38 / 40$ & $49 / 44$ & $57.8 / 59.8$ & 51 \\
CO [ppbv] & $119 / 118$ & $64^{*} / 66$ & $92 / 89$ & $106 / 92$ & $193 / 184$ & 92 \\
NOx [pptv] & $267 / 197$ & $50^{*} / 26$ & $76 / 47$ & $188 / 77$ & $297 / 59$ & $2221 / 393$ \\
NOy [pptv] & $897 / 1027$ & $223 / 188$ & $519 / 392$ & $958 / 231$ & $956 / 625$ & $4315 / 1340$ \\
HCHO [ppbv & $1.4 / 1.1$ & $0.3^{*} / 0.15$ & $1.4 / 1.1$ & n.a. & n.a. & $1.4 / 0.9$ \\
ROx [pptv] & 30.5 & 25.4 & 65 & n.a. & 17.5 & 32 \\
\hline
\end{tabular}

${ }^{1}$ Atlas and Ridley (1996); Cantrell et al. (1996); Zhou et al. (1996)

${ }^{2}$ Fischer et al. (1998)

${ }^{3}$ Zellweger et al. (2000)

${ }^{4}$ Carpenter et al. (2000)

${ }^{5}$ Cantrell et al. (1997); Harder et al. (1997); Williams et al. (1997)

*average values for noontime taken from Cantrell et al. (1996)

(Hawaii, $19.38^{\circ} \mathrm{N}, 155.36^{\circ} \mathrm{W}, 3400 \mathrm{~m}$ asl), Izana (Tenerife, $28.18^{\circ} \mathrm{N}, 16.3^{\circ} \mathrm{W}, 2370 \mathrm{~m}$ asl), Jungfraujoch (Swiss Alps, $46.33^{\circ} \mathrm{N}, 7.59^{\circ} \mathrm{W}, 3580 \mathrm{~m}$ asl), and Idaho Hill (Colorado, Rocky Mountains, $39.5^{\circ} \mathrm{N}, 105.37^{\circ} \mathrm{W}, 3070 \mathrm{~m}$ asl). The measurements at Mauna Loa were obtained during the Mauna Loa Observatory Photochemistry Experiment (MLOPEX) II intensive measurement campaign between 15 July and 15 August 1992 (Atlas and Ridley, 1996), while the measurements at Izana were made during the Oxidizing Capacity of the Tropospheric Atmosphere (OCTA) intensive from 31 July until 22 August 1994 (Fischer et al., 1998). Both sites are in remote marine environments in the North Pacific and Atlantic Oceans, respectively. In general, their high elevations guarantee access to the free troposphere, at least during the night and the early morning hours. Contrary to these sites, Idaho Hill, the Jungfraujoch, and Mt. Cimone are located in North America and Europe, thus representing continental background conditions. Measurements at Idaho Hill were obtained during the Tropospheric $\mathrm{OH}$ Photochemistry Experiment (TOPHE) in August/September 1993 (Mount and Williams, 1997). Intensive measurements at the Jungfraujoch were performed between 18 July and $23 \mathrm{Au}$ gust 1997 (Zellweger et al., 2000) and during the Free Tropospheric Experiment (FREETEX) between 19 March and 14 April 1998 (Carpenter et al., 2000). The data in Table 4 have been subdivided into free tropospheric and boundary layer influenced airmasses by averaging nighttime and daytime measurements, respectively. In general the trace gas levels listed in Table 4 reflect the remoteness of the sites, with lowest pollution levels observed at Mauna Loa for downslope conditions at night. The concentration levels for NOx, NOy, $\mathrm{CO}$, and $\mathrm{O}_{3}$ at Mt. Cimone are very similar to the summer 1997 measurements at the Jungfraujoch, indicating European continental background conditions. The HCHO levels at Mt. Cimone, Izana, and Idaho Hill are of the same order (0.9 $1.4 \mathrm{ppbv})$, while observations at Mauna Loa indicate much smaller concentrations $(0.15-0.3 \mathrm{ppbv})$. The noontime average ROx levels vary within a factor of two for the four sites.

\subsection{Ozone production}

The oxidation of $\mathrm{CO}$ and volatile organic compounds (VOC) in the presence of sufficient amounts of $\mathrm{NOx}\left(=\mathrm{NO}+\mathrm{NO}_{2}\right)$ can be considered as a significant source of tropospheric ozone (Crutzen, 1973, Chameides and Walker, 1973, Liu et al., 1980). During daylight hours $\mathrm{NO}_{2}$ is photolytically converted to $\mathrm{NO}$ leading to the formation of $\mathrm{O}_{3}$ :

$$
\begin{aligned}
& \mathrm{NO}_{2}+\mathrm{h} v(\lambda<424 \mathrm{~nm}) \longrightarrow \mathrm{NO}+\mathrm{O} \\
& \mathrm{O}+\mathrm{O}_{2}+\mathrm{M} \longrightarrow \mathrm{O}_{3}+\mathrm{M}
\end{aligned}
$$

Under most tropospheric conditions the dominant pathway by which $\mathrm{NO}$ is converted back to $\mathrm{NO}_{2}$ is via the reaction with $\mathrm{O}_{3}$ :

$\mathrm{NO}+\mathrm{O}_{3} \longrightarrow \mathrm{NO}_{2}+\mathrm{O}_{3}$

The sequence of reactions (R1), (R2), and (R3) constitutes a cycle with no net $\mathrm{O}_{3}$ production or destruction, but the photochemical oxidation of $\mathrm{CO}$ and VOC produces peroxy radicals $\left(\mathrm{HO}_{2}\right.$ and $\left.\mathrm{RO}_{2}\right)$ that provide additional $\mathrm{NO}$ to $\mathrm{NO}_{2}$ conversion routes:

$$
\begin{aligned}
& \mathrm{NO}+\mathrm{HO}_{2} \longrightarrow \mathrm{NO}_{2}+\mathrm{OH} \\
& \mathrm{NO}+\mathrm{RO}_{2} \longrightarrow \mathrm{NO}_{2}+\mathrm{RO}
\end{aligned}
$$




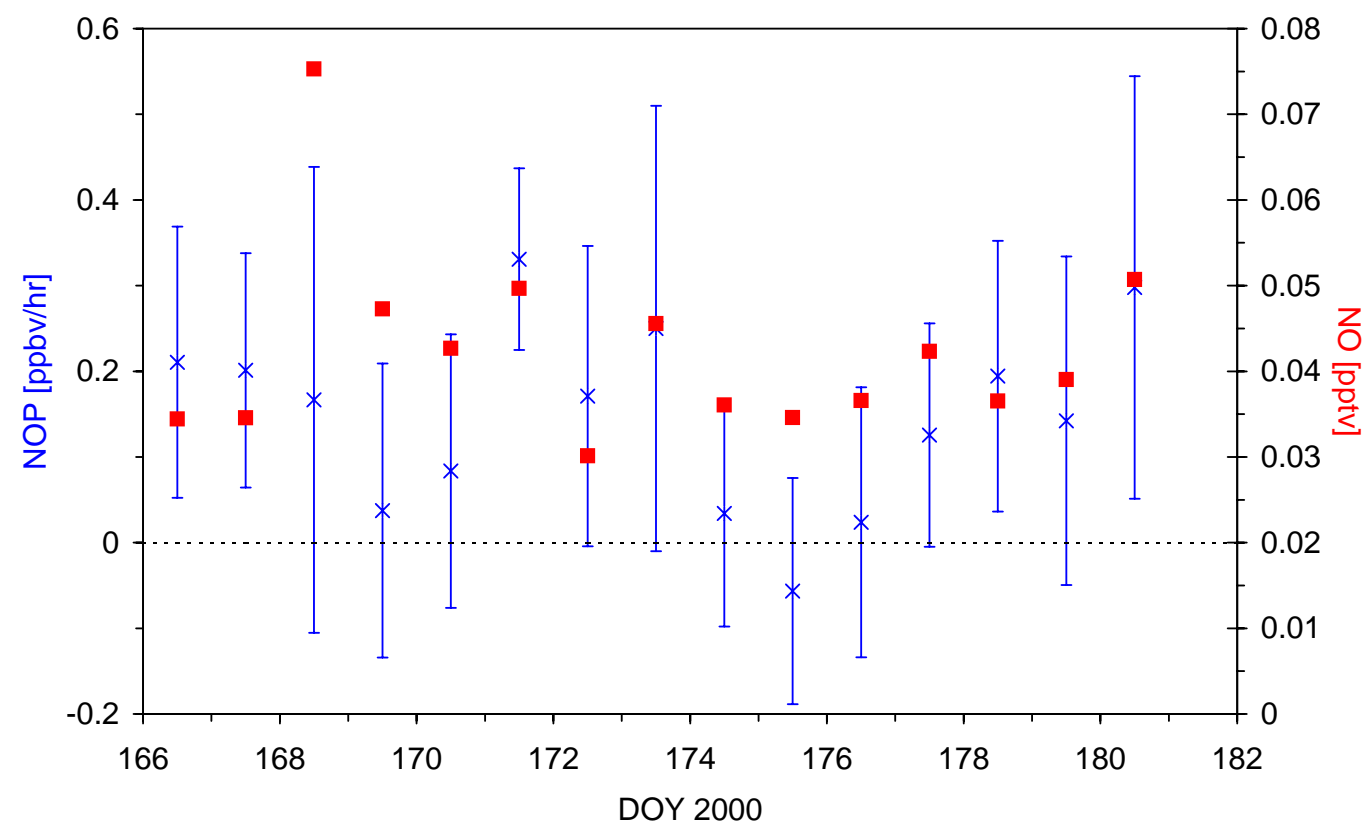

Fig. 3. Calculated daily mean (6-20 GMT) net ozone production (NOP) for the period between 14 June (DOY 166) and 28 June (DOY 180) (blue stars). The error bars indicate the $1 \sigma$-standard deviation. Red squares give the mean daytime NO concentration. Note that NO spikes due to local pollution have been omitted for this analysis.

In these reactions the conversion of $\mathrm{NO}$ to $\mathrm{NO}_{2}$ does not consume $\mathrm{O}_{3}$ so that the subsequent photolysis of $\mathrm{NO}_{2}$ (reaction R1 followed by reaction R2) represents a net source of $\mathrm{O}_{3}$. The peroxy radicals needed in (R4) and (R5) are formed mainly in the photochemical oxidation of $\mathrm{CO}$ and $\mathrm{CH}_{4}$ :

$$
\begin{aligned}
& \mathrm{CO}+\mathrm{OH}\left(+\mathrm{O}_{2}\right) \longrightarrow \mathrm{CO}_{2}+\mathrm{HO}_{2} \\
& \mathrm{CH}_{4}+\mathrm{OH}\left(+\mathrm{O}_{2}\right) \longrightarrow \mathrm{CH}_{3} \mathrm{O}_{2}+\mathrm{H}_{2} \mathrm{O}
\end{aligned}
$$

and in reactions of higher non-methane hydrocarbons with $\mathrm{OH}$.

Under the assumption that ozone is formed mainly via the oxidation of methane the ozone production rate is given as (Liu et al., 1980):

$\mathrm{P}\left(\mathrm{O}_{3}\right)=\left\{\mathrm{k}_{\mathrm{R}}\left[\mathrm{HO}_{2}\right]+\mathrm{k}_{\mathrm{R} 5}\left[\mathrm{CH}_{3} \mathrm{O}_{2}\right]\right\}[\mathrm{NO}]$

Note that through the reaction of NMHC with $\mathrm{OH}, \mathrm{RO}_{2}$ radicals other than $\mathrm{CH}_{3} \mathrm{O}_{2}$ are formed that can contribute to the ozone production.

The net ozone production is limited by radical termination reactions, e.g.:

$\mathrm{NO}_{2}+\mathrm{OH}+\mathrm{M} \longrightarrow \mathrm{HNO}_{3}+\mathrm{M}$

dominating at high NOx concentrations, and

$\mathrm{HO}_{2}+\mathrm{HO}_{2} \longrightarrow \mathrm{H}_{2} \mathrm{O}_{2}+\mathrm{O}_{2}$

$\mathrm{CH}_{3} \mathrm{O}_{2}+\mathrm{HO}_{2} \longrightarrow \mathrm{CH}_{3} \mathrm{OOH}+\mathrm{O}_{2}$

most significant at low NOx concentrations.
Ozone is lost by photolysis, producing an oxygen atom in an electronically excited state

$\mathrm{O}_{3}+\mathrm{h} v(\lambda<315 \mathrm{~nm}) \longrightarrow \mathrm{O}_{2}+\mathrm{O}\left({ }^{1} \mathrm{D}\right)$

that can either be quenched to the ground-state by collision with $\mathrm{N} 2$ or $\mathrm{O}_{2}$ or react with water vapour to form two hydroxyl radicals $(\mathrm{OH})$ :

$\mathrm{O}\left({ }^{1} \mathrm{D}\right)+\mathrm{H}_{2} \mathrm{O} \longrightarrow 2 \mathrm{OH}$

Additional losses of $\mathrm{O}_{3}$ are due to its reaction with either $\mathrm{OH}$ or $\mathrm{HO}_{2}$

$\mathrm{OH}+\mathrm{O}_{3} \longrightarrow \mathrm{HO}_{2}+\mathrm{O}_{2}$

$\mathrm{HO}_{2}+\mathrm{O}_{3} \longrightarrow \mathrm{OH}+2 \mathrm{O}_{2}$

If we assume that ozone losses due to dry deposition, heterogeneous reactions and up-take in cloud droplets, and reactions with alkenes are negligible, its loss term is

$\mathrm{L}\left(\mathrm{O}_{3}\right)=\left(\mathrm{fj}\left(\mathrm{O}^{1} \mathrm{D}\right)+\mathrm{k}_{\mathrm{R} 13}[\mathrm{OH}]+\mathrm{k}_{\mathrm{R} 14}\left[\mathrm{HO}_{2}\right]\right)\left[\mathrm{O}_{3}\right]$

where $\mathrm{j}\left(\mathrm{O}^{1} \mathrm{D}\right)$ is the ozone photolysis rate and $\mathrm{f}$ is the fraction of $\mathrm{O}\left({ }^{1} \mathrm{D}\right)$ atoms reacting with $\mathrm{H}_{2} \mathrm{O}$ to produce $\mathrm{OH}$ rather than being collisionally deactivated.

The difference between (1) and (2) describes the net ozone production:

$\mathrm{NOP}=\mathrm{P}\left(\mathrm{O}_{3}\right)-\mathrm{L}\left(\mathrm{O}_{3}\right)$ 


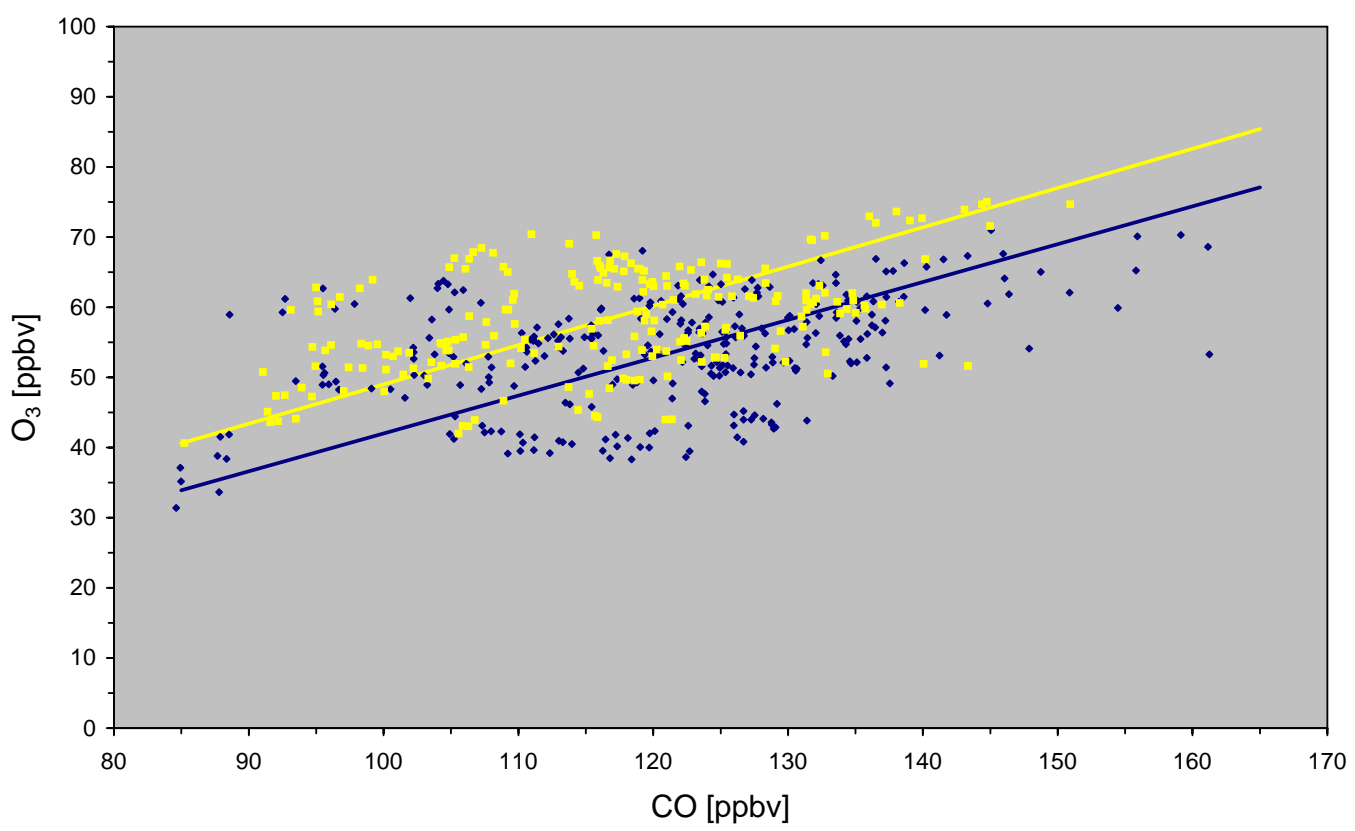

Fig. 4. Scatter plot of $\mathrm{O}_{3}$ versus CO. Daytime data (6-20 GMT) are printed as yellow squares, while nighttime (20-6 GMT) observations are printed as dark blue diamonds. The individual regression lines obtained from major reduced axis fits for day and night are shown as yellow $\left(\mathrm{O}_{3}=0.54 \mathrm{CO}-12 ; \mathrm{R}^{2}=0.19\right)$ and blue $\left(\mathrm{O}_{3}=0.56 \mathrm{CO}-7 ; \mathrm{R}^{2}=0.23\right)$ lines, respectively. A linear regression analysis for the combined data yields: $\mathrm{O}_{3}=0.56 \mathrm{CO}-12 ; \mathrm{R}^{2}=0.15$.

Equation (3) can be evaluated using chemical box models (e.g. Liu et al., 1980) or estimated from in-situ measurements of $\mathrm{O}_{3}, \mathrm{NO}, \mathrm{HO}_{2}+\mathrm{RO}_{2}, \mathrm{j}\left(\mathrm{O}^{1} \mathrm{D}\right), \mathrm{H}_{2} \mathrm{O}$, and temperature (Penkett et al., 1997; Zanis et al., 2000b). Here we follow the approach described in detail by Zanis et al. (2000b). The $\mathrm{OH}$ concentration, which was not measured at the site, was estimated according to Zanis et al. (2000a):

$$
\begin{aligned}
& \frac{\left[\mathrm{HO}_{2}\right]+\left[\mathrm{CH}_{3} \mathrm{O}_{2}\right]}{[\mathrm{OH}]}= \\
& \frac{\mathrm{k}_{\mathrm{R} 6}[\mathrm{CO}]+\mathrm{k}_{\mathrm{R} 7}\left[\mathrm{CH}_{4}\right]+\mathrm{k}_{\mathrm{R} 1}\left[\mathrm{O}_{3}\right]}{\mathrm{k}_{\mathrm{R} 4}[\mathrm{NO}]+\mathrm{k}_{\mathrm{R} 14}\left[\mathrm{O}_{3}\right]+2 \sqrt{\mathrm{k}^{\prime} \mathrm{j}\left(\mathrm{O}^{1} \mathrm{D}\right)\left[\mathrm{O}_{3}\right]}} \\
& \text { with }\left[\mathrm{CH}_{4}\right]=1800 \text { ppbv. } \\
& \quad \text { The coefficient k' is defined as }
\end{aligned}
$$

$\mathrm{k}^{\prime}=\left(\beta^{2} \mathrm{k}_{\mathrm{R} 9}+\beta \mathrm{k}_{\mathrm{R} 10}+\mathrm{k}_{\mathrm{R}\left(\mathrm{CH}_{3} \mathrm{O}_{2}+\mathrm{CH}_{3} \mathrm{O}_{2}\right)}\right) /(\beta+1)^{2}$

where $\beta=\left[\mathrm{HO}_{2}\right] /\left[\mathrm{CH}_{3} \mathrm{O}_{2}\right]$.

As first shown by Penkett et al. (1997) scatter plots of $\left[\mathrm{HO}_{2}\right]+\left[\mathrm{RO}_{2}\right]$ versus $\left(\mathrm{j}\left(\mathrm{O}^{1} \mathrm{D}\right)\right)^{1 / 2}$ can be used to derive an experimental value for $\mathrm{k}$ ' from the gradient of a fitted regression line on the data, while $\beta=1$ was derived from in situ $\mathrm{HO}_{2}$ and $\mathrm{RO}_{2}$ measurements at Mt. Cimone using the Heidelberg ROXMAS instrument (Uecker et al., 2001). Note that Zanis et al. (2000b) derived a much higher value for $\beta$ of 4-7 using a box model to simulate the $\mathrm{HO}_{2} / \mathrm{CH}_{3} \mathrm{O}_{2}$ ratio at the Jungfraujoch. Sensitivity studies indicate that NOP would decrease by $11 \%$ for $\beta=5$.
Figure 3 shows the mean daytime (06:00-20:00 GMT) net ozone production (NOP) rate ( $\pm 1 \sigma$-standard deviation), which gives an estimate of the on-site ozone tendency in a present-time frame. As such it describes the potential for ozone production in these airmasses in a Lagrangian experiment. The NOP evaluated for the period between 14 June (DOY 166) and 28 June (DOY 180) varies between approximately zero (23 June, DOY 175) and 0.2-0.3 ppbv/hr, indicating that 2-3 ppbv of ozone can be expected to be formed in these airmasses in the course of one day. Figure 2 shows that the average ozone concentration increases from a minimum value around noon (ca. $54 \mathrm{ppbv}$ ) to a late afternoon maximum of the order of $60 \mathrm{ppbv}$, which is of the same order of magnitude as the estimated net ozone production. Note, that a direct comparison is difficult due to the experimental set-up. While the NOP describes the photochemical ozone production in an Lagrangian frame, the observed increase of ozone at the site itself is due to local chemistry and advection of airmasses with different ozone content (Eulerian frame). Figure 3 also shows the average daily NO concentration, which is approximately $40 \mathrm{pptv}$.

The NOP measured at the site is comparable to the daily average net ozone production rates deduced for the Jungfraujoch during the FREETEX'98 campaign in March/April 1998, that varied from around $0.1 \mathrm{ppbv} / \mathrm{hr}$ for relatively clean days to more than $1 \mathrm{ppbv} / \mathrm{hr}$ during the more polluted days at average daily NO mixing ratios of 27.3 and $260.5 \mathrm{pptv}$, respectively (Zanis et al., 2000b). Contrary to the positive 


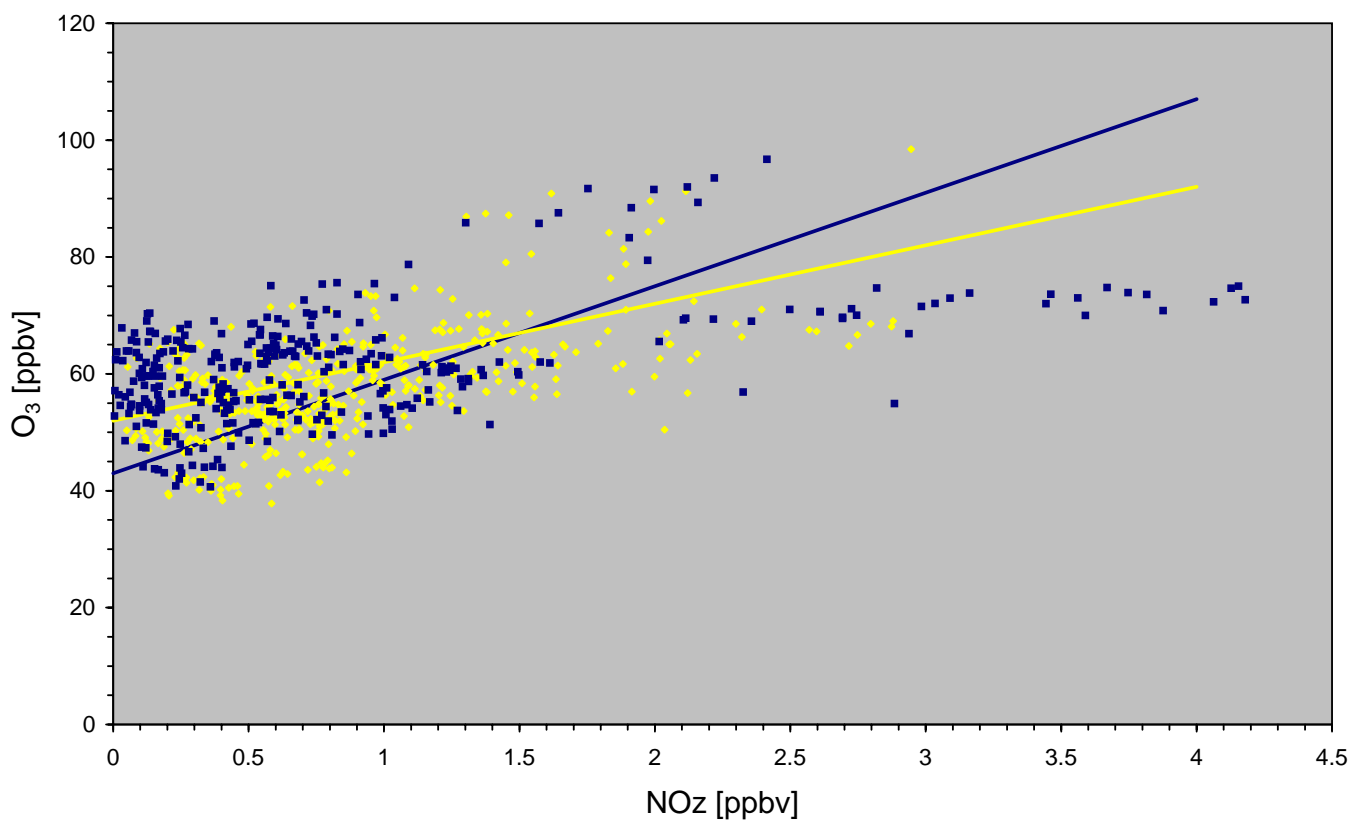

Fig. 5. Scatter plot of $\mathrm{O}_{3}$ versus NOz, defined as the difference between NOy and NOx. Daytime data (6-20 GMT) are printed as yellow squares, while nighttime (20-6 GMT) observations are printed as dark blue diamonds. The individual regression lines obtained from major reduced axis fits for day and night are shown as yellow $\left(\mathrm{O}_{3}=16 \mathrm{NOz}+43 ; \mathrm{R}^{2}=0.33\right)$ and blue $\left(\mathrm{O}_{3}=10 \mathrm{NOz}+52 ; \mathrm{R}^{2}=0.22\right)$ lines, respectively. A linear regression analysis for the combined data yields: $\mathrm{O}_{3}=13 \mathrm{NOz}+48 ; \mathrm{R}^{2}=0.27$.

NOP derived for these two mountainous sites in continental Europe, Cantrell et al. (1996) deduced a negative NOP $(-0.15 \mathrm{ppbv} / \mathrm{hr}$ ) for a mean NO concentration of $19 \mathrm{pptv}$ at Mauna Loa during MLOPEX II in summer 1992, a remote site in the central North Pacific. The compensation point, where the production and destruction of ozone are in balance, is related to the NO concentrations in the range of 5-50 pptv depending on the conditions in the probed airmass, which explains the difference between net ozone destruction at Mauna Loa compared to net ozone production at the continental European site cited above.

\subsection{Trace gas relations}

In the preceding section we used a present-time frame method based on observational quantities to estimate the onsite net ozone production at Mt. Cimone. To describe the net $\mathrm{O}_{3}$ production during the transport of airmasses to the site, past-time frame techniques can be applied (Kleinman, 2000). Such methods are generally based on relations among $\mathrm{O}_{3}$ with $\mathrm{CO}, \mathrm{NOy}$ or $\mathrm{NOz}(=\mathrm{NOy}-\mathrm{NOx})$ (for a recent review see Trainer et al., 2000). A positive correlation between $\mathrm{O}_{3}$ and $\mathrm{CO}$ can be expected if one assumes that $\mathrm{CO}$ is a proxy for the amount of reactive carbon ( $\mathrm{CO}$ and hydrocarbons) used during $\mathrm{O}_{3}$ production (Fishman et al., 1980). A slope of $\sim 0.3$ has been observed in $\mathrm{O}_{3}-\mathrm{CO}$ scatter plots at various rural and remote sites in moderately polluted boundary layer air (Parrish et al., 1993; Chin et al., 1994; Parrish et al., 1998), while no significant correlation is found in the middle and upper troposphere (Fishman et al., 1980; Fischer et al., 2002). Figure 4 shows $\mathrm{O}_{3}-\mathrm{CO}$ scatter plots for the measurements at Mt. Cimone. Positive correlations between these species are observed during day and night with slopes of the order of 0.5 , based on a reduced major axis fit accounting for errors in both the $\mathrm{x}$ and the $\mathrm{y}$-variable, These values are slightly higher than observations at other sites in North America (Chin et al., 1994), the Atlantic coast of Canada (Parrish et al., 1993) and the central Atlantic ocean (Fischer et al., 1998; Parrish et al., 1998) during summer. Note that the majority of these results (Parrish et al., 1993; Chin et al., 1994; Fischer et al., 1994) are based on single sided linear regressions accounting only for errors in $\mathrm{O}_{3}$. A similar procedure would yield slopes of the order of 0.25 for the MINATROC data set, a value in much better agreement with these literature values.

Nevertheless, the correlation coefficients of the $\mathrm{O}_{3}-\mathrm{CO}$ relations at Mt. Cimone are rather small, most probably indicating significant contributions to the $\mathrm{O}_{3}$ budget at the site associated with transport from the middle and upper free troposphere.

Trainer et al. (1993) found that a positive correlation exists between $\mathrm{O}_{3}$ and the oxidation products of $\mathrm{NOx}$, i.e. $\mathrm{NOz}$ $=$ NOy - NOx. This is a consequence of the fact that the rate of ozone formation is indirectly related to the rate of NOx oxidation to NOz (Liu et al., 1987; Trainer et al., 1993). Thus the slope of $\mathrm{O}_{3}-\mathrm{NOz}$ scatter plots has been interpreted as an estimate of the amount of $\mathrm{O}_{3}$ formed per ppbv of $\mathrm{NOx}$ 


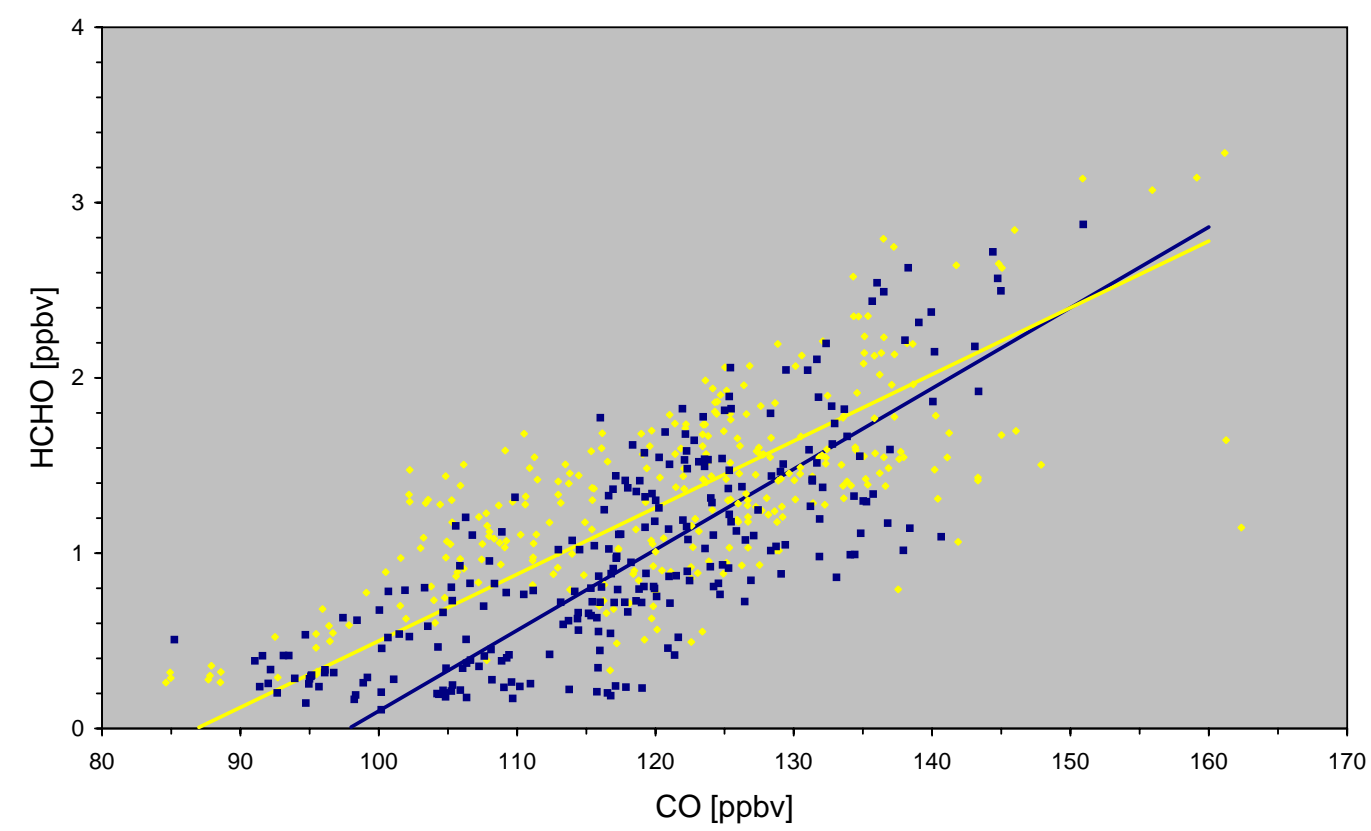

Fig. 6. Scatter plot of HCHO versus CO. Daytime data (6-20 GMT) are printed as yellow squares, while nighttime (20-6 GMT) observations are printed as dark blue diamonds. The individual regression lines obtained from major reduced axis fits for day and night are shown as yellow $\left(\mathrm{HCHO}=0.038 \mathrm{CO}-3.3 ; \mathrm{R}^{2}=0.47\right)$ and blue $\left(\mathrm{HCHO}=0.046 \mathrm{CO}-4.5 ; \mathrm{R}^{2}=0.59\right)$ lines, respectively. A linear regression analysis for the combined data yields: $\mathrm{HCHO}=0.043 \mathrm{CO}-4 ; \mathrm{R}^{2}=0.54$.

oxidized. However, this slope is further affected by the relative rates of chemical and physical (dry deposition and rainout) removal of $\mathrm{O}_{3}$ and $\mathrm{NOz}$ (in particular its major constituent $\mathrm{HNO}_{3}$ ), and by the mixing of air parcels of different histories (Trainer et al., 2000). Therefore, the slope of an $\mathrm{O}_{3}-\mathrm{NOz}$ scatter plot in general provides only a lower limit of the gross ozone production efficiency. Figure 5 shows the correlation among these species obtained at Mt. Cimone. The slope is about 16 (based on a reduced major axis fit) which is somewhat higher than observations in the eastern United States that showed values of $\Delta \mathrm{O}_{3} / \Delta \mathrm{NOz}$ between 8 and 12 (e.g. Trainer et al., 1993; Poulida et al., 1994; Kleinmann et al., 1994). Lower values of 4-6 $\Delta \mathrm{O}_{3} / \Delta \mathrm{NOz}$ were observed in the city plume of Freiburg at Schauinsland (VolzThomas et al., 1993). The large scatter and the subdivision into two branches in Fig. 5 is most probably due to dry deposition and rainout of $\mathrm{HNO}_{3}$, or mixing of airmasses with different histories, both of which tend to modify the slope of the regression and the correlation coefficient. The upper branch in Fig. 5 consists of data points with high $\mathrm{O}_{3}$ values ( $>75 \mathrm{ppbv}$ ). These data are mainly due to observations made during late afternoons of 2, 3, and 9 June. In particular the pollution event in the late afternoon (18:00-23:00 GMT) of 9 June, when the highest concentrations of NOx, NOy, $\mathrm{O}_{3}$ and $\mathrm{HCHO}$ were observed, contributes to this particular branch of the $\mathrm{O}_{3}$-NOz correlation $\left(\mathrm{R}^{2}=0.54\right)$. The slope of the regression analysis for this branch is larger than 16 indicating rather high ozone production in freshly polluted airmasses
$(\mathrm{NOx} / \mathrm{NOy}>0.3)$. Note that this branch is not present in the $\mathrm{O}_{3}$-CO scatter plot, since $\mathrm{CO}$ measurements are not available before 14 June. The lower branch in Fig. 5 is characterized by $\mathrm{NOz}$ values in excess of $1.5 \mathrm{ppbv}$ and $\mathrm{O}_{3}$ values less than $75 \mathrm{ppbv}\left(\mathrm{R}^{2}=0.45\right)$. These airmasses are characterized by significantly smaller NOx/NOy ratios $(<0.2)$ indicating more processed air (during the nights of 1-2, 16-17 June and during the day of 18 June).

Much higher correlation coefficients are observed for a number of scatter plots involving $\mathrm{HCHO}$, an intermediate in the oxidation of methane and higher hydrocarbons. A particularly significant correlation was observed for $\mathrm{HCHO}$ and $\mathrm{CO}$ (overall $\mathrm{R}^{2}=0.54$ ) (Fig. 6), while weaker correlations were observed for $\mathrm{HCHO}$ and NOy (overall $\mathrm{R}^{2}=0.4$ ) (Fig. 7) and $\mathrm{HCHO}$ and $\mathrm{O}_{3}$ (overall $\mathrm{R}^{2}=0.37$ ) (Fig. 8). The HCHO-NOy scatter plot is again composed of two branches, corresponding to the airmass classification discussed already for the $\mathrm{O}_{3}-\mathrm{NOz}$ relation. Here the freshly polluted airmass has higher HCHO levels ( $>2 \mathrm{ppbv}$ ), than the more processed, aged airmass ( $\mathrm{HCHO}<2 \mathrm{ppbv})$. Again this separation cannot be identified in the HCHO-CO scatter plot due to the missing $\mathrm{CO}$ measurements before 14 June. In the HCHO$\mathrm{O}_{3}$ scatter plot the plume associated with the freshly polluted airmass is clearly visible at $\mathrm{O}_{3}>75$ ppbv.

If one restricts the analysis to those days that were not affected by clouds (clear sky days: DOY 155, 157, 165, $171,173,174,175)$ the HCHO vs. CO and HCHO vs. NOy correlations are even stronger with $\mathrm{R}^{2}=0.73$ and 0.82 , 


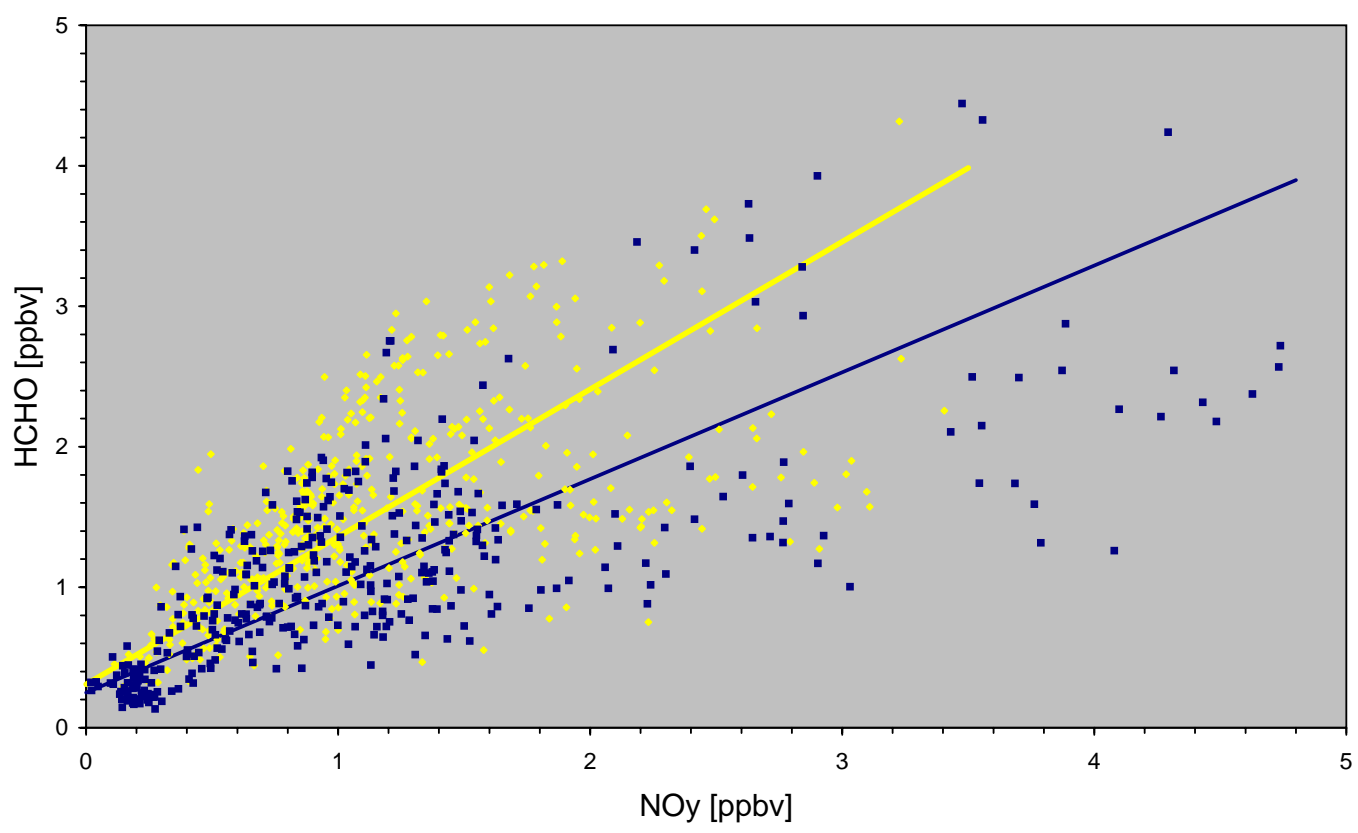

Fig. 7. Scatter plot of HCHO versus NOy. Daytime data (6-20 GMT) are printed as yellow squares, while nighttime (20-6 GMT) observations are printed as dark blue diamonds. The individual regression lines obtained from major reduced axis fits for day and night are shown as yellow $\left(\mathrm{HCHO}=1.05 \mathrm{NOy}+0.31 ; \mathrm{R}^{2}=0.35\right)$ and blue $\left(\mathrm{HCHO}=0.76 \mathrm{NOy}+0.25 ; \mathrm{R}^{2}=0.51\right)$ lines, respectively. A linear regression analysis for the combined data yields: $\mathrm{HCHO}=0.92 \mathrm{NOy}+0.3 ; \mathrm{R}^{2}=0.40$.

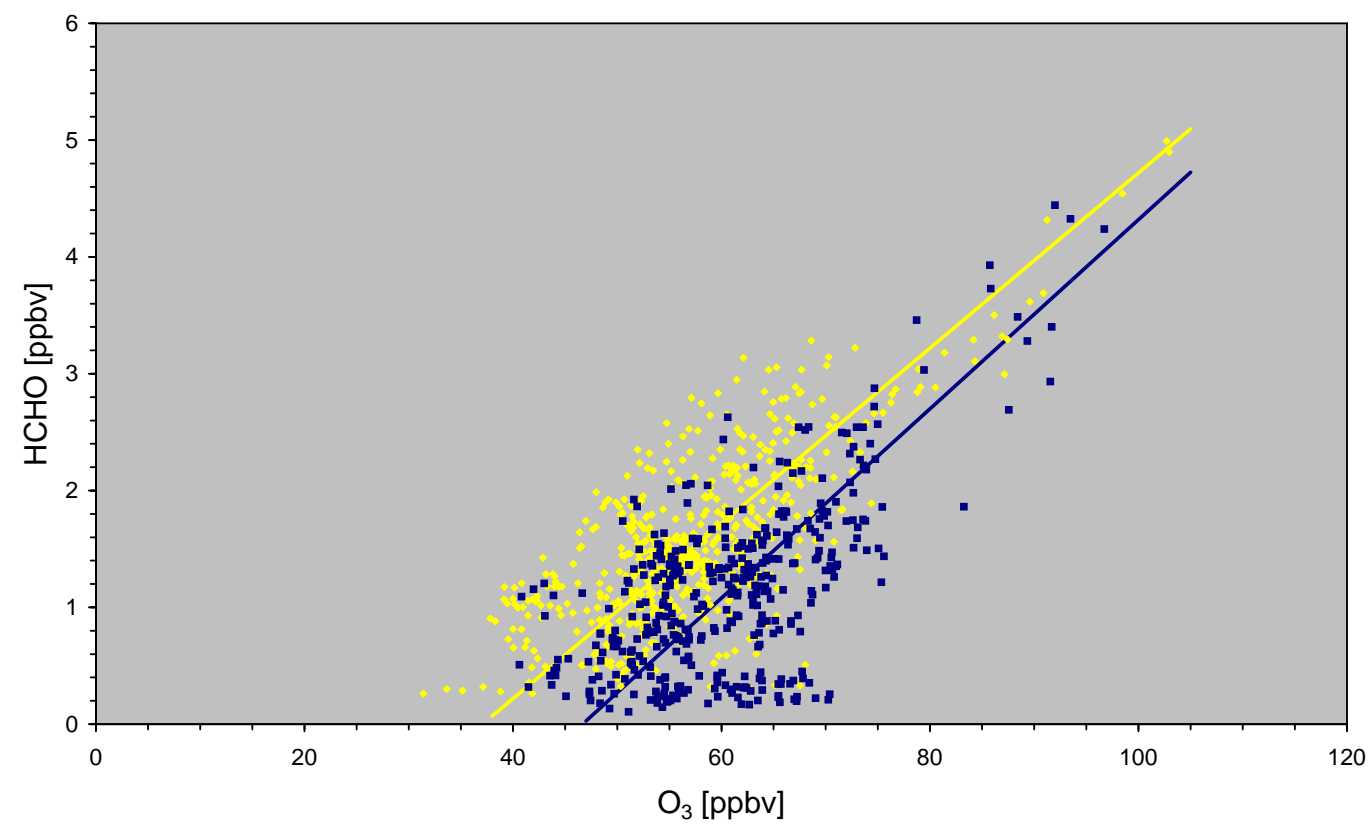

Fig. 8. Scatter plot of $\mathrm{HCHO}$ versus $\mathrm{O}_{3}$. Daytime data (6-20 GMT) are printed as yellow squares, while nighttime (20-6 GMT) observations are printed as dark blue diamonds. The individual regression lines obtained from major reduced axis fits for day and night are shown as yellow $\left(\mathrm{HCHO}=0.075 \mathrm{O}_{3}-2.78 ; \mathrm{R}^{2}=0.55\right)$ and blue $\left(\mathrm{HCHO}=0.081 \mathrm{O}_{3}-3.78 ; \mathrm{R}^{2}=0.41\right)$ lines, respectively. A linear regression analysis for the combined data yields: $\mathrm{HCHO}=0.079 \mathrm{O}_{3}-3.29 ; \mathrm{R}^{2}=0.37$. 
respectively. On the other hand, the effect of the data filtering on the correlation coefficients for $\mathrm{HCHO}$ vs. $\mathrm{O}_{3}, \mathrm{O}_{3}$ vs. $\mathrm{NOz}$ and $\mathrm{O}_{3}$ vs. $\mathrm{CO}$ is not significant.

A correlation between $\mathrm{CO}$ and $\mathrm{HCHO}$ is usually interpreted as an indication of nearby anthropogenic emission sources (Neitzert and Seiler, 1981; Cardenas et al., 1999) or the influence of biomass burning (Mauzerall et al., 1998). Nevertheless, a positive correlation among these species has recently been observed in the remote marine boundary layer over the Indian Ocean, far away from anthropogenic or biomass burning sources (Wagner et al., 2001). To estimate the contribution from direct emissions, the $\mathrm{HCHO} / \mathrm{CO}$ area emission ratio for eastern North America $5.6 \cdot 10^{-3}$ (Li et al., 1994 ) is used. The slope of the regression analysis for Fig. 6 gives a ratio almost an order of magnitude higher $\left(4 \cdot 10^{-2}\right)$, confirming that direct emissions most probably contribute little to the observed correlation. It is likely that secondary $\mathrm{HCHO}$ formation from volatile organic compounds is at least partially responsible for the observed correlation. In this case $\mathrm{CO}$ would serve as a proxy for VOCs associated with combustion processes, which is further supported by the observed correlation of NOy vs. HCHO (Fig. 7) and NOy vs. CO (not shown).

\section{Conclusions}

Continuous trace gas measurements of $\mathrm{O}_{3}, \mathrm{CO}, \mathrm{NO}, \mathrm{NO}_{2}$, $\mathrm{NOy}, \mathrm{HCHO}$ and ROx, together with the photolysis rate of $\mathrm{O}_{3}\left(\mathrm{j}\left(\mathrm{O}^{1} \mathrm{D}\right)\right)$ and analysis of canister samples for VOCs were made during the MINATROC intensive summer campaign at the Mt. Cimone station (Italy, $44^{\circ} 11^{\prime} \mathrm{N}-10^{\circ} 42^{\prime} \mathrm{E}$, $2165 \mathrm{~m}$ asl) between 1 and 30 June 2000. In general, mean trace gas mixing ratios are relatively low $(\mathrm{CO}=(121 \pm 20)$ ppbv, $\mathrm{NOx}=(0.284 \pm 0.220) \mathrm{ppbv}, \mathrm{NOy}=(1.15 \pm 0.8)$ ppbv, $\left.\mathrm{O}_{3}=(58 \pm 9 \mathrm{ppbv})\right)$ (Table 1$)$, which points to a low level of local pollution. Those trace gas levels are representative of continental background air, which is further supported by the analysis of VOCs (e.g.: $\mathrm{C}_{2} \mathrm{H}_{6}=(905 \pm 200)$ pptv, $\mathrm{C}_{3} \mathrm{H}_{8}=(268 \pm 110)$ pptv, $\mathrm{C}_{2} \mathrm{H}_{2}=(201 \pm 102)$ pptv, $\mathrm{C}_{5} \mathrm{H}_{8}=(111 \pm 124) \mathrm{pptv}$, benzene $\left.=(65 \pm 33) \mathrm{pptv}\right)$. The trace gas concentrations at Mt. Cimone are comparable to measurements at two other mountain sites, the Jungfraujoch in the Swiss Alps (Zanis et al., 2000b) and Idaho Hill, Colorado (Cantrell et al., 1997; Harder et al., 1997; Williams et al., 1997), while they are higher than observations at the remote N-Pacific location Mauna Loa (Atlas and Ridley, 1996; Cantrell et al., 1996; Zhou et al., 1997).

Average mid-day peroxy radical concentrations at Mt. Cimone are of the order of $30 \mathrm{pptv}$. At mean NO concentrations of the order of $40 \mathrm{pptv}$ this gives rise to significant in-situ net $\mathrm{O}_{3}$ production at the site $(0.1-0.3 \mathrm{ppbv} / \mathrm{hr})$.

Significant photochemical $\mathrm{O}_{3}$ production is further supported by correlations between $\mathrm{O}_{3}, \mathrm{CO}$, or $\mathrm{NOz}$. The slopes of these correlations $\left(\sim 0.5\right.$ for $\mathrm{O}_{3} / \mathrm{CO} ; \sim 13$ for $\left.\mathrm{O}_{3} / \mathrm{NOz}\right)$ are comparable to reported observations from North America, Europe, or the central Atlantic (Trainer et al., 1993; Parrish et al., 1993; Poulida et al., 1994; Kleinmann et al., 1994; Chin et al., 1994; Fischer et al., 1998; Parrish et al., 1998). The large slope of the observed $\mathrm{HCHO} / \mathrm{CO}$ correlation indicates that $\mathrm{HCHO}$ production at the site has a strong contribution from the oxidation of longer lived VOCs that are emitted along with $\mathrm{CO}$. The fact that $\mathrm{HCHO}$ is also significantly correlated with NOy (NOy itself is strongly correlated with $\mathrm{CO}$ ) indicates that the $\mathrm{HCHO}$ precursors are mainly associated with anthropogenic combustion processes.

Acknowledgements. We gratefully acknowledge the excellent collaboration with the Mt. Cimone staff members, in particular, Mr. F. Calzolari and Mr. Cristofanelli. This work was supported by the European Commission (DG XII) within the framework of the MINATROC and STACCATO projects.

\section{References}

Atlas, E. L. and Ridley, B. A.: The Mauna Loa Observatory Photochemistry Experiment: Introduction, J. Geophys. Res., 101, 14 531-14 541, 1996.

Balkanski, Y., Bauer, S. E., van Dingenen, R., Bonasoni, P., Schulz, M., Fischer, H., Gobbi, G. P., Hanke, M., Hauglustaine, D., Putaud, J. P., and Stohl, A.: Overall presentation of the campaign of Mt. Cimone, Italy; principle characteristics of the gaseous and aerosol composition from European pollution, Mediterranean influences, and during African dust events, this issue.

Bonasoni, P., Stohl, A., Cristofanelli, P., Calzolri, F., Colombo, T., and Evangelisti, F.: Background ozone variations at Mt. Cimone station, Atmos. Environm., 34, 5183-5189, 2000.

Bonasoni, P., Cristofanelli, P., van Dingenen, R., Calzolari, F., Bonafe, U., Colombo, T., Evangelista, F., Tositti, L., and Balkanski, Y.: Aerosol and ozone correlation during the transport episodes of the summer-autumn 2000 period, this issue.

Cantrell, C. A., Shetter, R. E., Gilpin, T. M., and Calvert, J. G.: Peroxy radical measured during the Mauna Loa Observatory Photochemistry Experiment 2: The data and first analysis, J. Geophys. Res., 101, 14 643-14 652, 1996.

Cantrell, C. A., Shetter, R. E., Calvert, J. G., Eisele, F. L., Williams, E., Baumann, K., Brune, W. H., Stevens, P.S., and Mather, J.H.: Peroxy radicals from photostationary state deviations and steady state calculations during the Tropospheric $\mathrm{OH}$ Photochemistry Experiment at Idaho Hill, Colorado, 1993, J. Geophys. Res., 102, 6369-6378, 1997.

Cardenas, L. M., Mills, G., and Penkett, S. A.: Tropospheric measurements of formaldehyde, Proceedings of EUROTRAC Symposium '98, 356-360, 1999.

Carpenter, L. J., Green, T. J., Mills, G. P., Bauguitte, S., Penkett, S. A., Zanis, P., Schuepbach, E., Schmidbauer, N., Monks, P. S., and Zellweger, C.: Oxidized nitrogen and ozone production efficiencies in the springtime free troposphere over the Alps, J.Geophys. Res., 105, 15 547-15 559, 2000.

Chameides, W. and Walker, J. C. G.: A photochemical theory of tropospheric ozone, J. Geophys. Res., 78, 8751-8760, 1973. 
Chin, M., Jacob, D. J., Munger, J. W., Parrish, D. D., and Doddridge, B. G.: Relationship of ozone and carbon monoxide over North America, J. Geophys. Res., 99, 14 565-14 573, 1994.

Crutzen, P. J.: A discussion of the chemistry of some minor constituents in the stratosphere and troposphere, Pure Appl. Geophys., 106, 1385-1399,1973.

Crutzen, P. J.: Ozone in the troposphere, in Composition, Chemistry, and Climate of the Atmosphere, H.B. Singh (Ed), Van Norstrand Reinhold, New York, pp. 349-393, 1995.

van Dingenen, R., Putaud, J. P., Roselli, D., Dell'Aqua, A., Perrone, M. P., Bonasoni, P., and Facchini, M. C.: Comprehensive characterisation of aerosol physical and chemical properties of the aerosol at Mt. Cimone, this issue.

Fischer, H., Nikitas, C., Parchatka, U., Zenker, T., Harris, G. W., Matuska, P., Schmitt, R., Mihelcic, D., Muesgen, P., Paetz, H.W., Schulz, M., and Volz-Thomas, A.: Trace gas measurements during the Oxidizing Capacity of the Tropospheric Atmosphere campaign 1993 at Izana, J. Geophys. Res., 103, 13 505-13 518, 1998.

Fischer, H., Brunner, D., Harris, G. W., Hoor, P., Lelieveld, J., McKenna, D. S., Rudolph, J., Scheeren, H. A., Siegmund, P., Wernli, H., Williams, J., and Wong, S.: Synoptic tracer gradients in the upper troposphere over central Canada during the STREAM 1998 summer campaign, J. Geophys. Res., 107(8),10.1029/2000JD000312, 2002.

Fishman, J., Seiler, W., and Haagenson, P.: Simultaneous presence of $\mathrm{O}_{3}$ and $\mathrm{CO}$ bands in the troposphere, Tellus, 32, 456-463, 1980

Harder, J. W., Fried, A., Sewell, S., and Henry, B.: Comparison of tunable diode laser and long- path ultraviolet/visible spectroscopic measurements of ambient formaldehyde concentrations during the 1993 OH Photochemistry Experiment, J. Geophys. Res., 102, 6267-6282, 1997.

Hanke, M., Uecker, J., Reiner, T., and Arnold, F.: Atmospheric peroxy radicals: ROXMAS, a new mass-spectrometric methodology for speciated measurements of $\mathrm{HO}_{2}$ and $\sum \mathrm{RO}_{2}$ and first results, Int. J. Mass Spectr., 213, 91-99, 2002.

Hanke, M., Umann, B., Uecker, J., Arnold, F., and Bunz, H.: Atmospheric measurements of gas-phase $\mathrm{HNO}_{3}$ and $\mathrm{SO}_{2}$ with chemical ionisation mass spectrometry during the first MINATROC filed campaign at Monte. Cimone, 2000, this issue.

Hastie, D. R., Weissenmayer, M., Burrows, J. P., and Harris, G. W.: Calibrated chemical amplifier for atmospheric ROx measurements, Anal. Chem., 63, 2048-2057, 1991.

Holton, J. R., Haynes, P. H., McIntyre, M. E., Douglass, A. R., Rood, R. B., and Pfister, L.: Stratosphere-troposphere exchange, Rev. of Geophys., 33, 403-439, 1995.

Kleinman, L., Lee, Y.-N., Sprinston, S. R., Nunnermacker, L., Zhou, X., Brown, R., Hallock, K., Klotz, P., Leahy, D., Lee, J. H., and Newman, L.: Ozone formation at a rural site in the southern United States, J. Geophys. Res., 99, 3469-3482, 1994.

Kleinman, L. I.: Ozone production insights from field experiments - part II: Observation- based analysis for ozone production, Atmos.Environm., 34, 2023-2033, 2000.

Kormann, R., Fischer, H., Gurk, C., Helleis, F., Klüpfel, Th., Königstedt, R., Parchatka, U., and Wagner, V.: Application of TRISTAR, a three-laser tunable diode laser absorption spectrometer during MINATROC, Spectrochimica Acta, A58, 2489-2498, 2002.
Lange, L., Fischer, H., Parchatka, U., Gurk, C., Zenker, T., and Harris, G. W.: Characterization of an externally mounted catalytic converter for aircraft measurements, Rev. Scient. Instr., 73, 3051-3057, 2002.

Li, S.-M., Anlauf, K. G., Wiebe, A., and Bottenheim, J. W.: Estimating primary and secondary production of $\mathrm{HCHO}$ in eastern North America based on gas phase measurements and principal component analysis, Geophys. Res. Lett., 21, 669-672, 1994.

Liu, S. C., Kley, D., McFarland, M., Mahlmann, J. D., and Levy II, H.: On the origin of tropospheric ozone, J. Geophys. Res., 85, 7546-7552, 1980

Liu, S. C., Trainer, M., Fehsenfeld, F. C., Parrish, D. D., Williams, E. J., Fahey, D. W., Hübler, G., and Murphy, P. C.: Ozone production in the rural troposphere and the implications for regional and global ozone distributions, J. Geophys. Res., 92, 4191-4207, 1987.

Mauzerall, D. L., Logan, J. A., Jacob, D. J., Anderson, B. E., Blake, D. R., Bradshaw, J. D., Heikes, B., Sachse, G. W., Singh, H., and Talbot, B.: J. Geophys. Res., 103, 8401-8423, 1998.

Mihele, C. M. and Hastie, D. R.: The sensitivity of the radical amplifier to ambient water vapour, Geophys. Res. Lett., 25, 19111913, 1998.

Mount, G. H. and Williams, E. J.: An overview of the Tropospheric OH Photochemistry Experiment, Fritz Peak/Idaho Hill, Colorado, fall 1993, J. Geophys. Res., 102, 6171-6186, 1997.

Mühle, J., Zahn, A., Brenninkmeijer, C. A. M., Gros, V., and Crutzen, P. J.: Air mass classification during the INDOEX R/V Ronald Brown cruise using measurements of non-methane hydrocarbons, $\mathrm{CH}_{4}, \mathrm{CO}_{2}, \mathrm{CO},{ }^{14} \mathrm{CO}$ and $\delta^{18} \mathrm{O}(\mathrm{CO})$, J. Geophys. Res., 107, D(19), 10.129/2001JD000730, 2002.

Neitzert, V. and Seiler, W.: Measurement of formaldehyde in clean air, Geophys. Res. Lett., 8, 79-82, 1981.

Parrish, D. D., Holloway, J. S., Trainer, M., Murphy, P. C., Forbes, G. L., and Fehsenfeld, F. C.: Export of North American ozone pollution to the North Atlantic Ozean, Science, 259, 1436-1439, 1993.

Parrish, D. D., Trainer, M., Holloway, J. S., Yee, J. E., Warshawsky, M., Fehsenfeld, F. C., Forbes, G. L., and Moody, J. L.: Relationships between ozone and carbon monoxide at surface sites in the North Atlantic region, J. Geophys. Res., 103, 13 357-13 376, 1998 .

Penkett, S. A., Monks, P. S., Carpenter, L. J., Clemitshaw, K. C., Ayers, G. P., Gillet, R. W., Galbally, I. E., and Meyer, C. P.: Relationships between ozone photolysis rates and peroxy radical concentrations in clean marine air over the southern ozean, J. Geophys. Res., 102, 12 805-12 817, 1997.

Perner, D., Arnold, T., Crowley, J., Klüpfel, T., Martinez, M., and Seuwen, R.: The measurement of active chlorine in the atmosphere by chemical amplification, J. Atmos. Chem., 34, 9-20, 1999.

Poulida, O., Civerolo, K. L., and Dickerson, R. E.: Observations and tropospheric photochemistry in central North Carolina, J. Geophys. Res., 99, 10 553-10 563, 1994.

Ridley, B. A. and Robinson, E.: The Mauna Loa photochemistry experiment, J. Geophys. Res., 97, 10 285-10 290, 1992.

Schultz, M., Heitlinger, M., Mihelcic, D., and Volz-Thomas, A.: Calibration source for peroxy radicals with built-in actinometry using $\mathrm{H}_{2} \mathrm{O}$ and $\mathrm{O}_{2}$ photolysis at $185 \mathrm{~nm}$, J. Geophys. Res., 100, $18811-18816,1995$. 
Stohl, A., Wotawa, G., Seibert, P., and Kromp-Kolb, H.: Interpolation errors in wind fields as a function of spatial and temporal resolution and their impact on different types of kinematic trajectories, J. Appl. Meteorology, 34, 2149-2165, 1995.

Trainer, M., Parrish, D. D., Buhr, M. P., Norton, R. B., Fehsenfeld, F. C., Anlauf, K. G., Bottenhwim, J. W., Tang, Y. Z., Wiebe, H. A., Roberts, J. M., Tanner, R. L., Newman, L., Bowersox, V. C., Meagher, J. F., Olszyna, K. J., Rodgers, M. O., Wang, T., Berresheim, H., Demerjian, K. L., and Roychowdhury, U. K.: Correlation of ozone with NOy in photochemically aged air, J. Geophys. Res., 98, 2917-2925, 1993.

Trainer, M., Parrish, D. D., Goldon, P. D., Roberts, J., and Fehsenfeld, F. C.: Review of the observation-based analysis of the regional factors influencing ozone concentrations, Atmos. Environ., 34, 2045-2061, 2000.

Uecker, J., Hanke, M., and Arnold, F.: First speciated atmospheric measurements of $\mathrm{HO}_{2}$ and organic peroxy radicals $\left(\sum \mathrm{RO}_{2}\right)$ by chemical conversion/ion molecule reaction mass spectrometry (ROXMAS) before, during and after the major mineral dust intrusion on Monte Cimone during the first MINATROC field campaign in June-July 2000, Proceedings of the 8th European Symposium on the Physico-Chemical Behaviour of Atmospheric Pollutants, 17-20 September 2001, Torino (IT), J. Hjorth, F. Raes, and G. Angeletti (Eds), 2001

Volz-Thomas, A., Mihelcic, D., Müsgen, P., Pätz, H. W., Pilwat, G., Geiss, H., and Kley, D.: Photo-oxidants and precursors at Schauinsland, Black Forest, Proc. EUROTRAC Symposium '92, Borell, P. M., Borell, P., Cvitas, T., and Seiler, W. (Eds), SPB Academic Publishing, The Hague, The Netherlands, pp. 98-103, 1993.

Wagner V., Schiller, C., and Fischer, H.: Formaldehyde measurements in the marine boundary layer of the Indian Ocean during the 1999 INDOEX cruise of the RV Ronald H. Brown, J. Geophys. Res., 106, 28 529-28 538, 2001.
Wagner, V., von Glasow, R., Fischer, H., and Crutzen, P. J.: Are $\mathrm{CH}_{2} \mathrm{O}$ measurements in the marine boundary layer suitable for testing the current understanding of the $\mathrm{CH}_{4}$ photooxidation? - A model study, J. Geophys. Res., 107(3), 101029/2001JD000722, 2002.

Wienhold, F. G., Fischer, H., Hoor, P., Wagner, V., Königstedt, R., Harris, G. W., Anders, J., Grisar, R., Knothe, M., Riedel, W. J., Lübken, F.-J., and Schilling, T.: TRISTAR - a tracer in-situ TDLAS for atmospheric research, Appl. Phys. B, 67, 411-417, 1998.

Williams, E. J., Roberts, J. M., Baumann, K., Bertman, S. B., Buhr, S., Norton, R. B., and Fehsenfeld, F. C.: Variations in NOy composition at Idaho Hill, Colorado, J. Geophys. Res., 102, 62976314, 1997.

Zanis, P., Monks, P. S., Schuepbach, E., and Penkett, S. A.: The role of in situ photochemistry in the control of ozone during spring at the Jungfraujoch ( $3580 \mathrm{~m}$ asl) - Comparison of model results with measurements, J. Atmos. Chem., 37, 1-27, 2000a.

Zanis, P., Monks, P. S., Schuepbach, E., Carpenter, L. J., Green, T. J., Mills, G. P., Bauguitte, S., and Penkett, S. A.: In situ ozone production under free tropospheric conditions during FREETEX'98 in the Swiss alps, J. Geophys. Res., 105, 24 223-24 234, 2000b.

Zaveri, R. A., Saylor, R. D., Peters, L. K., McNider, R., and Song, A.: A model investigation of summertime diurnal ozone behaviour in rural mountainous locations, Atmos. Environm., 29, 1043-1065, 1995.

Zellweger, C., Ammann, M., Buchmann, B., Hofer, P., Lugauer, M., Rüttimann, R., Streit, N., Weingartner, E., and Bltensperger, U.: Summertime NOy speciation at the Jungfraujoch, $3580 \mathrm{~m}$ above sea level, Switzerland, J. Geophys. Res., 105, 6655-6667, 2000.

Zhou, X., Lee, Y.-N., Newman, L., Chen, X., and Mopper, K.: Tropospheric formaldehyde concentration at the Mauna Loa Observatory Photochemistry Experiment 2, J. Geophys. Res., 101, 14711-14 719, 1996. 